FACULDADES EST

PROGRAMA DE PÓS-GRADUAÇÃO MESTRADO PROFISSIONAL EM TEOLOGIA

JORGE EUGENIO DE ALMEIDA

IGREJAS E ESCOLA: UMA PROPOSTA PARA O ENFRENTAMENTO À VIOLÊNCIA NAS ESCOLAS MUNICIPAIS EM TAUBATÉ-SP

São Leopoldo 

JORGE EUGENIO DE ALMEIDA

IGREJAS E ESCOLA: UMA PROPOSTA PARA O ENFRENTAMENTO À VIOLÊNCIA NAS ESCOLAS MUNICIPAIS EM TAUBATÉ-SP

\author{
Trabalho Final de \\ Mestrado Profissional \\ Para a obtenção do grau de \\ Mestre em Teologia \\ Faculdades EST \\ Programa de Pós-Graduação \\ Mestrado Profissional em Teologia \\ Área de Concentração: Teologia Prática \\ Linha de Pesquisa: Educação \\ Comunitária com Infância e Juventude.
}

Orientadora: Prof. ${ }^{a}$ Dr.. Laude Erandi Brandenburg

São Leopoldo

2019 
Dados Internacionais de Catalogação na Publicação (CIP)

A447i Almeida, Jorge Eugenio de

Igrejas e escola : uma proposta para o enfrentamento à violência nas escolas municipais em Taubaté-SP / Jorge Eugenio de Almeida ; orientadora Laude Erandi

Brandenburg. - São Leopoldo : EST/PPG, 2019.

65 p. ; $31 \mathrm{~cm}$

Dissertação (Mestrado) - Faculdades EST. Programa de Pós-Graduação. Mestrado em Teologia. São Leopoldo, 2019.

1. Violência na escola. 2. Violência na escola Prevenção. 3. Obras da igreja junto aos estudantes. I. Brandenburg, Laude Erandi, orientadora. II. Título.

Ficha elaborada pela Biblioteca da EST 


\title{
IGREJAS E ESCOLA: UMA PROPOSTA PARA O ENFRENTAMENTO À VIOLÊNCIA NAS ESCOLAS MUNICIPAIS EM TAUBATÉ-SP.
}

\author{
Trabalho Final de \\ Mestrado Profissional \\ Para a obtenção do grau de \\ Mestre em Teologia \\ Faculdades EST \\ Programa de Pós-Graduação em Teologia \\ Área de Concentração: Teologia Prática \\ Linha de Pesquisa: Educação \\ Comunitária com Infância e Juventude.
}

Data de Aprovação: 24 de março de 2020.

Prof. Dr.. Laude Erandi Brandenburg (Presidente)

Participação por webconferência

Prof. Dr. Nilton Eliseu Herbes (EST)

Participação por webconferência

Prof. Dr. Joel Haroldo Baade (UNIARP)

Participação por webconferência 

Dedico este trabalho a Deus, que com sua bondade e misericórdia, me amou incondicionalmente. 


\section{AGRADECIMENTOS}

À minha esposa Evanice Sampaio Eugenio de Almeida, meu amor, meu tesouro. "Ainda que eu falasse a língua dos anjos, sem amor eu nada seria." (I Coríntios 13).

Aos meus filhos Yago e Vitor, presentes de Deus na minha vida.

À minha avó Maria Silva, minha mãe Manoelina Eugenia, e meu pai João Baptista (in memoriam), meus primeiros professores, meus heróis. "Por muito tempo achei que a ausência é falta. E lastimava ignorante, a falta. Hoje não a lastimo. Não há falta na ausência. A ausência é um estar em mim". (Carlos Drummond de Andrade)

Às minhas irmãs, com quem compartilhei a minha infância: "Sou hoje um caçador de achadouros da infância. Vou meio dementado e enxada às costas cavar no meu quintal vestígios dos meninos que fomos". (Manoel de Barros).

Aos meus professores de todas as etapas da minha formação educacional, pelo investimento incalculável em minha vida.

À minha orientadora, Profa. Dra. Laude Erandi, por me orientar na direção certa, e por todo o carinho expresso por cada gesto, correção, crítica e elogios.

À direção da Escola Municipal Ensino Infantil e Fundamental Profa. Docelina Silva de Campos Coelho, em Taubaté-SP, pela confiança, disponibilidade e oportunidade, que contribuiu diretamente para esta pesquisa, me ajudando a cumprir mais uma nobre missão.

Meu muito obrigado! 
"A paz, se possível, mas a verdade a qualquer preço!"

"Quando a escola progride, tudo progride!"

Martinho Lutero 



\section{RESUMO}

A violência tem feito diversas vítimas em diferentes setores da sociedade. É um fenômeno que assola a sociedade como um todo. Não se restringindo somente aos grandes centros urbanos, mas também às cidades de interior e áreas rurais. Este cenário de violência também se estabeleceu nas escolas de forma alarmante. Portanto este trabalho visa identificar as diferentes formas de violência que estão ocorrendo no ambiente escolar e propor uma parceria entre as Igrejas e a Escola, como uma alternativa para o enfrentamento da violência no ambiente escolar. Analisando os possíveis fatores de conflitos que geram violência, as possíveis consequências, e o que está sendo feito para estabelecer uma cultura de paz e promover bons relacionamentos em meio ao cenário pós-moderno. Esta pesquisa tem o objetivo de reunir informações que sirvam como base para que as escolas possam enfrentar um dos seus maiores desafios: educar, e complementar afetivamente aquilo que falta nos lares. Também visa contribuir para restauração dos laços familiares e incentivar a parceria da família com a escola para que haja uma convivência harmoniosa e motivadora em prol da construção da cidadania de crianças, jovens e adolescentes. Sendo assim, para atingir este objetivo foi feita uma pesquisa exploratória (Gil, 2002) ${ }^{1}$ nas informações veiculadas nas mídias sociais, junto a Secretaria de Educação e Delegacia Seccional de Polícia Civil de TaubatéSP, em busca de possíveis registros documentais sobre violência e suas consequências, possíveis soluções adotadas e seus resultados. Esta pesquisa visa, ainda, conhecer o que de fato está sendo empregado como política pública para 0 enfrentamento da violência na escola. Para coleta de dados, foram realizadas as análises dos documentos oficiais de acesso público da Secretaria de Educação do Município de Taubaté, das reportagens publicadas pela mídia, e das informações constantes nos relatórios policiais, que tratam dos crimes ocorridos nas escolas e nos entornos delas. A metodologia de análise utilizada foi a de análise de conteúdo (Bardin, 2009). ${ }^{2}$ Estas análises documentais foram fundamentais para este trabalho, pois a partir delas foi possível identificar os principais fatores que desencadeiam 0 processo que gera a violência nas escolas municipais da cidade de Taubaté-SP.

Palavras-chave: Igreja. Escola. Parceria. Enfrentamento. Violência. Capelania Escolar. Projetos. Família. Convivência harmoniosa. 



\begin{abstract}
Violence has claimed various victims in different sectors of society. It is a phenomenon that plagues society as a whole. It is not restricted only to large urban centers, but also [occurs] in inland cities and rural areas. This scenario of violence has also established itself in schools in an alarming way. Therefore, this work aims to identify the different forms of violence that are occurring in the school environment and to propose a partnership between the Churches and the School, as an alternative to face violence in the school environment. It analyzes the possible conflict factors that generate violence, the possible consequences, and what is being done to establish a culture of peace and promote good relationships in the midst of the postmodern scenario. This research aims to gather information that serves as a basis for schools to face one of their greatest challenges: to educate, and to affectionately complement what is lacking in homes. It also aims to contribute to the restoration of family ties and encourage the partnership of the family with the school so that there is a harmonious and motivating coexistence in favor of building the citizenship of children, young people and adolescents. Therefore, in order to achieve this objective, an exploratory research was carried out (Gil, 2002) on the information conveyed on social media, with the Department of Education and the Civil Police Section of Taubaté-SP, in search of possible documentary records on violence and its consequences, possible solutions adopted and their results. This research also aims to find out what is actually being used as a public policy to confront violence at school. For data collection, analyses of official publicly accessible documents from the Department of Education of the Municipality of Taubaté were carried out, as well as of reports published by the media, and information contained in police reports, which deal with crimes occurring in and around schools. The analysis methodology used was that of content analysis (Bardin, 2009). These documentary analyses were fundamental for this work, since it was possible to identify the main factors that trigger the process that generates violence in municipal schools in the city of Taubaté-SP.
\end{abstract}

Keywords: Church. School. Partnership. Confronting. Violence. School Chaplaincy. Projects. Family. Harmonious Coexistence. 



\section{SUMÁRIO}

1 INTRODUÇÃO

2 HISTÓRICO DA VIOLÊNCIA E SUAS POSSÍVEIS CAUSAS E EFEITOS............19

2.1 Buscando pistas para compreender as causas da violência ...................19

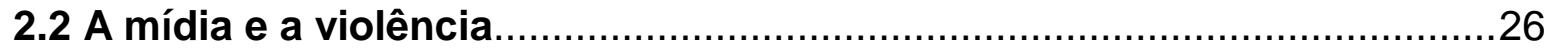

2.3 A problemática da violência nas escolas municipais em Taubaté-SP ......28

3 A PARCERIA DAS IGREJAS COM ESCOLA, E A APLICABILIDADE DAS

MEDIDAS PROTETIVAS PREVISTAS NO ESTATUTO DA CRIANÇA E DO

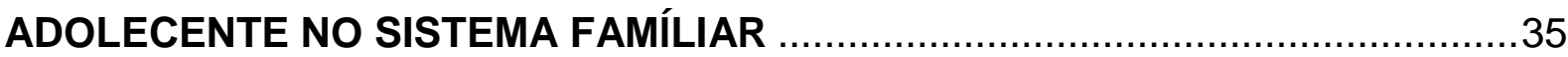

3.1 A história da capelania e da capelania escolar ..........................................

3.2 A estrutura relacional e comportamental das pessoas crianças e

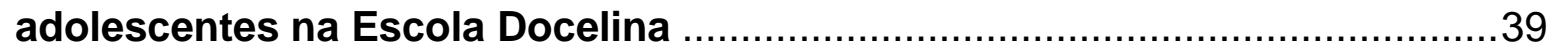

3.3 O Professor e o Capelão, e a comunicação relacional ............................42

4 ENTRANDO EM AÇÃO: POSSIBILIDADES E PROJETOS ….........................4

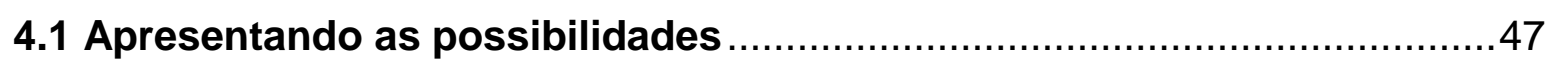

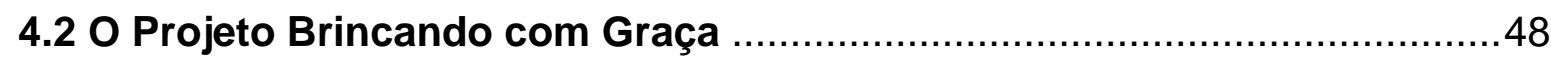

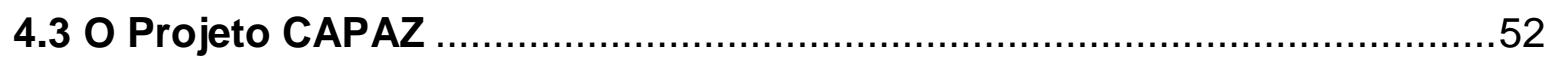

5 CONCLUSÃO

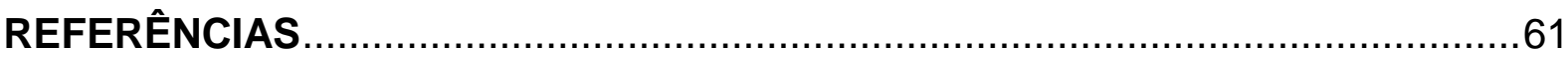





\section{INTRODUÇÃO}

Ao longo desses dois anos, no curso de mestrado profissional da Faculdade EST, me foi transmitido conhecimento, que me deu respaldo teórico para experimentar na prática, pesquisar um dos temas atuais e muito presente na sociedade brasileira: a violência escolar. E sendo assim poder propor uma parceria entre as Igrejas e a Escola para o enfrentamento desse fenômeno.

Nilo Odália, filósofo, historiador e professor da UNESP, descreve que a violência está "tão entranhada no nosso dia-a-dia, que pensar e agir em função dela deixou de ser um ato circunstancial, para se transformar num modo de ver e de viver o mundo do homem". 3

A sociedade quer soluções, busca respostas, e se encontra cada vez mais incrédula com a justiça. E, assim, cada vez que a desigualdade e a injustiça prevalecem, a sociedade passa a tentar resolver os seus problemas, da forma que considera mais justa. Esta estratégia muitas vezes gera ainda mais violência. Já por outro lado, parece que a violência se tornou banal, como se o convívio diário com ela fosse natural e aceitável.

Sob o ponto de vista da Profa. Dra. Silvia Parrat-Dayan a violência sofrida por professores e alunos no ambiente escolar, é um tema atual e muito presente na sociedade brasileira. Ainda, é considerada como fator que interfere na prática pedagógica do professor em diferentes níveis de ensino ${ }^{4}$, traduzindo-se em obstáculos no que se refere ao processo ensino-aprendizagem, uma vez que dificultam o exercício da função de docentes e o desenvolvimento dos conhecimentos apresentados por parte de discentes envolvidos. ${ }^{5} \mathrm{E}$ é aí, portanto, que este trabalho tem a sua relevância, pois a Igreja visa propiciar a humanidade uma visão espiritual que gera esperança, e que dá sentido aos acontecimentos do dia a dia e ao modo de vida no mundo, e pode guiar uma série de decisões sobre o que é o ser humano. Sob o ponto de vista sistêmico, a Igreja, a Escola, e a Família

ODALIA, N. O que é violência? São Paulo: Brasiliense, 2004. p. 9.

PARRAT-DAYAN, S. Como enfrentar a indisciplina na escola. Tradução de Silva Beatriz Adoue e Augusto Juncal. São Paulo: Contexto, 2008. p. 143.

5 VASCONCELLOS, C. dos S.(In) Disciplina: Construção da disciplina consciente e interativa em sala de aula e na escola. 17 Ed. São Paulo: Libertard, 2009. p. 24. 
exercem papéis diferentes, mas que cooperam para a formação da identidade, maturidade e crescimento das pessoas crianças e adolescentes.

Tendo em vista a experiência de vida deste pesquisador, como estudante do ensino fundamental na Escola Municipal Juliano Moreira, localizada na Comunidade da Cidade de Deus, no subúrbio do Rio de Janeiro-RJ, fato este que me aproxima da realidade encontrada nas escolas municipais da periferia de Taubaté-SP, e me leva expor neste trabalho meu notório saber em alguns fatos percebidos no momento da pesquisa. Mas, ainda assim, procuro abordar o presente tema embasando-o com os referenciais teóricos, a qual caracteriza a pesquisa científica.

Para atingir os objetivos propostos, o presente trabalho foi elaborado a partir de uma pesquisa bibliográfica e documental, com o objetivo de investigar: se há fatores que desencadeiam o processo que gera violência nas escolas municipais em Taubaté-SP e quais são as diferentes formas de violências que estão ocorrendo no ambiente escolar. Apresentar alguns projetos das Igrejas e o serviço voluntário de capelania escolar como uma ferramenta de cooperação à rede de proteção da infância e adolescência, e suas contribuições na mediação de conflitos, prevenção e intervenção à violência escolar.

Este estudo, além de ter como objetivo a consolidação do trabalho final do curso de mestrado profissional, também procura contribuir para a produção e divulgação de conhecimento acerca do papel sócioeducativo e espiritual da Igreja e seus projetos de prestação de serviço voluntário na escola.

A dissertação foi estruturada com uma introdução, mais três capítulos, e a conclusão. Eles são conectados da seguinte forma: no primeiro capítulo a introdução, onde é apresentado o contexto, metodologia, e conteúdo da pesquisa.

No segundo capítulo, é apresentado um histórico da violência e suas possíveis causas e efeitos.

No terceiro capítulo, é dado enfoque à possibilidade de uma parceria entre as Igrejas e a Escola, e a aplicabilidade das medidas protetivas previstas no Estatuto da Criança e do Adolescente no sistema familiar.

No quarto capítulo, são apresentados as possibilidades e os projetos desenvolvidos pelas igrejas na escola. Enfim, é encerrado com uma breve conclusão. 


\section{HISTÓRICO DA VIOLÊNCIA E SUAS POSSÍVEIS CAUSAS E EFEITOS}

\subsection{Buscando pistas para compreender as causas da violência}

É oportuno neste momento conceituar o termo violência, para que possamos ter uma maior compreensão deste fenômeno na escola. É "qualidade de quem é violento; abuso da força; tirania; opressão; veemência; ação violenta; coação; física ou moral". ${ }^{6}$ É viver de maneira desregrada, a vida em sociedade. É a transgressão da ordem pública, sem levar em conta os direitos da pessoa do próximo.

A família é o lugar onde se ouvem as primeiras falas com as quais se constroem a autoimagem e a imagem do mundo exterior. Assim, é fundamentalmente como lugar de aquisição de linguagem que a família define seu caráter social. Nela, aprende-se a falar e, por meio da linguagem, a ordenar e dar sentido às experiências vividas. A família, seja qual for sua composição e sua organização, é o filtro através do qual se começa a ver e a significar o mundo. Esse processo que se inicia ao nascer prolonga-se ao longo de toda a vida, a partir dos diferentes lugares que se ocupa na família. ${ }^{7}$

Com frequência surgem conflitos entre os pais e seus filhos adolescentes. Em virtude desses conflitos, pode surgir uma barreira de comunicação. Os pais acham difícil conversar com seus filhos. Eles atrasam as explicações sobre transformações cruciais, tanto físicas como mentais, especialmente nas áreas do sexo e da reprodução. Os pais intensificam o controle, e o adolescente luta ainda mais para obter independência. A fissura se abre, eles se tornam antagonistas, e a batalha continua.

Os pais como líderes de suas famílias precisam proteger, dar direção e estabelecer limites aos seus filhos.

Os pais têm perdido o governo de suas famílias e os filhos têm reagido contra a autoridade dos pais. Esta reação, causada pela ausência de limites, estende-se para o ambiente escolar, culminando em atos de violência verbal e física. Neste sentido, Fernández descreve que "o fenômeno da violência transcende a

6 FERNANDES, Francisco; LUFT, Celso Pedro; GUIMARÃES, F. Marques. Dicionário Brasileiro Globo. 46 ed., São Paulo, 1996.

7 SARTI, Cynthia Andersen. O jovem na família: o outro necessário. São Paulo, Ed. Fundação Perseu Abramo, 2004, p.120. 
mera conduta individual e se converte em um processo interpessoal, por afetar pelo menos dois protagonistas: aquele que a exerce e aquele que a sofre". ${ }^{8}$

A família, a escola e a igreja são essenciais elementos da socialização e da educação para os jovens, e, dessa maneira, de maior força e compromisso. Alguns aspectos familiares podem contribuir sendo fatores de risco para a violência dos jovens: a falta de afeto entre os cônjuges somando à ausência de segurança e de carinho; a omissão de negociação e de diálogo; os maus tratos e o exemplo violento no íntimo da família; a desestruturação da família; os métodos utilizados com a criança, podendo ser permissivos e inconsistentes, ou, ao contrário, práticas extremamente punitivas.

A família é importante na formação integral do ser humano. É no ambiente familiar, que inicialmente, o indivíduo tem os primeiros contatos com os princípios universais. Onde serão abordados valores e virtudes, que os acompanharão em sua jornada de vida. Por isso é de extrema importância que o capelão escolar atue como um elo de cooperação entre a escola, o aluno, e a família, com o intuito de facilitar a efetivação dos direitos inerentes à convivência familiar, permeando-a com princípios, valores e virtudes.

Os pais devem estabelecer regras para governo de sua família, que sejam justas e razoáveis. E sempre pautadas no respeito mútuo. $O$ respeito se aprende pela reação à autoridade. $E$ os filhos, no que diz respeito à autoridade, se espelham nos pais desde sua infância.

Os pais precisam encorajar e apoiar seus filhos. E serem flexíveis, no que diz respeito à identidade, independência e autoestima dos filhos. Os filhos, principalmente os adolescentes precisam de muito apoio e encorajamento. Os conflitos nunca se resolvem com discussões ou brigas. Uma comunicação consistente com o adolescente ajudará a evitar os conflitos. Isso inclui não apenas a conversa significativa, mas o tempo perdido com outras atividades com cada adolescente, individualmente. Essa atenção especial ajudará a criar uma autoimagem positiva e fortalecerá a solidariedade familiar.

8 FERNÁNDEZ, I. Prevenção da violência e solução de conflitos: o clima escolar como fator de qualidade. São Paulo, Ed. Madras, 2005. p. 24. 
Existem diferentes discursos sobre violência no país. Os que atribuem a culpa ao paradigma econômico (pobreza e desigualdade social), e à existência de uma cultura e indústria da violência, deixam de lado questões como: violência de gênero, homofobia, preconceito étnico, intolerância religiosa, rivalidades entre torcidas de futebol, manifestações sociais, dentre outros tantos, que transcendem uma visão limitada das causas desse fenômeno complexo que é a violência. ${ }^{9}$

Segundo José Murilo de Carvalho: "a cultura do consumo dificulta o desatamento do nó que torna tão lenta a marcha da cidadania entre nós, qual seja, a incapacidade do sistema representativo de produzir resultados que impliquem a redução da desigualdade e o fim da divisão dos brasileiros em castas". ${ }^{10}$ Assim desigualdade, no entendimento do autor é o "que impede a constituição de uma sociedade democrática". ${ }^{11}$

Várias circunstâncias antecedem a manifestação desse fenômeno tão complexo, e poucas são as autoridades que o admitem como tal, deixando assim de mapear todas as suas nascentes, a fim de estabelecer a melhor estratégia de enfrentamento. Desta forma, a violência é reconhecida como uma patologia social, que sempre se atribui ao outro, sem cogitar as responsabilidades pessoais, mesmo que indiretas, nas suas várias formas de expressão ${ }^{12}$. E sendo, assim, os indivíduos preferem transferir a sua parcela de responsabilidade, no processo de transformação deste quadro caótico, como se não tivesse consciência que a mudança começa em nós, o micro, e se propaga para toda a sociedade, o macro.

Embora a violência seja um fenômeno de grande complexidade, é passível de entendimento e de intervenções específicas que visam o seu combate. Pois ela gera preocupações em relação às suas possíveis consequências, formas e lugares que ela possa se manifestar. Outro fato preocupante acerca da violência é que ela tem moldado a forma de pensar e agir da sociedade, a ponto de ser vista como algo imodificável e ao mesmo tempo aceitável, gerando conformismo diante dela, fazendo com que sejam construídas verdadeiras muralhas, com concertinas,

9 ZALUAR, Alba. Integração Perversa: Pobreza e Tráfico de Drogas. Rio de Janeiro: FGV, 2004. p. 158.

10 CARVAlHo, José Murilo de. Cidadania no Brasil: o longo caminho. 5 ed. Rio de Janeiro: Civilização Brasileira, 2004. p. 228.

11 CARVALHO, 2004, p. 229.

12 ROLIM, Marcos. Discursos Selecionados: Pronunciamento do Deputado Federal Marcos Rolim PT/RS. Grande Expediente da Sessão Plenária do dia 21 de janeiro de 2000. Disponível em: <http://www.rolim.com.br/discur10.htm>. Acesso em: 18 mar. 2019. 
segurança eletrônica, pessoal e armada, como se fosse um forte preparado para a guerra, onde poucos se sentem privilegiados, por ter condições econômicas para morar dentro desses condomínios fechados. Mas, estas estratégias, por sua vez, têm promovido uma falsa sensação de segurança e um isolamento da realidade social, e isto se torna uma barreira para que o ser humano perceba que diversos atos cometidos por ele mesmo, sejam violência. "Perceber um ato como violência demanda do homem um esforço para superar sua aparência de ato rotineiro, natural e como que inscrito na ordem das coisas", pois nem sempre ela se apresenta "como um ato, como uma relação, como fato, que possuam uma estrutura facilmente identificável". ${ }^{13}$ E é exatamente por se acostumar com esta aparência de segurança, que estes atos rotineiros têm causado uma tragédia silenciosa dentro dos lares, seja dos ricos ou dos pobres, atingindo os nossos filhos e nossas filhas, e a sociedade como um todo.

Diante dessa exposição de informações é que a capelania escolar é apresentada neste trabalho final como uma proposta de cooperação junto à escola a fim de buscar soluções possíveis e práticas para aproximar e desenvolver a empatia no ambiente escolar, entre os e as estudantes, professores, professoras, cooperadores, cooperadoras e suas famílias. O objetivo é prover fortes redes de apoio social e envolver toda comunidade escolar em um trabalho conjunto Intergeracional, visando envolver as gerações a colaborar com sua opinião e seu trabalho a missão da escola. Este esforço de cooperação mútua visa tornar a escola um ambiente seguro e promissor.

É fato que os alicerces familiares têm sido abalados pelas expressivas mudanças, advindas da pós-modernidade. E muitos são os fatores que tem contribuído para o desalinho e desordem da família. Ocorre que, a liberdade de expressão e o desenfreado relativismo pós-moderno, desencadearam uma vertiginosa decadência da moralidade de forma globalizada. A família que outrora era o berço da educação tem sido saqueada em suas tradições e bons costumes, e as novas gerações prosseguem desamparadas do afeto familiar, cujo valor é inestimável por diversas razões. E a pior notícia desta constatação é que a escola nunca deixou de ser extensão do lar e, por conseguinte tem sido sobrecarregada pelos maléficos efeitos da desorganização familiar generalizada.

13 ODALIA, 2004, p. 22-23. 
A desorganização familiar generalizada tem gerado uma geração de crianças, jovens e adolescentes, inseguros, apáticos, vivendo muito mais o mundo virtual que o real, sexualmente precoces, medrosos, fragilizados, abandonados, intolerantes, egocêntricos, depressivos, ausentes, com autoestima baixa, solitários e angustiados. E o resultado disto segundo estudos da Universidade Federal do Estado de São Paulo (UNIFESP), são os seguintes dados alarmantes em relação ao comportamento dessa geração de jovens e adolescentes brasileiros: - De 50.890 alunos, em 27 capitais, 15,4\% (7.837) crianças entre 10 e 12 anos fazem uso contínuo de álcool; - O Ministério da Saúde registrou em 2016, 11433 mortes por suicídio, o equivalente a 31 casos por dia, e foi à quarta causa de morte entre jovens de 15 a 29 anos, em 2015; - O Brasil apresentou o maior número de mortes por arma de fogo no mundo. 59\% são jovens; - O Brasil tem 68 bebês nascidos de mães adolescentes a cada mil meninas de 10 a 19 anos. São cerca de 700 mil partos de mães adolescentes por ano; - No Brasil a evasão escolar é de 48,8 milhões de alunos. Sendo que 40,8\% não concluem o ensino médio até os 19 anos; - Segundo a APEOESP (Associação dos Professores do Ensino Oficial do Estado de São Paulo) $44 \%$ dos professores já sofreram algum tipo de violência em sua unidade escolar no estado; - O Brasil registrou mais de 26 mil assassinatos no $1^{\circ}$ semestre de 2018, sem contar os dados do Maranhão, Paraná e Tocantins. ${ }^{14}$

A escola é uma instituição consolidada que, além de possuir mecanismo de produção social e cultural, também produz sua própria violência. E sendo assim, necessita que seja estudada por diversas áreas do conhecimento, por se constituir uma instituição mais aberta e plural, principalmente a educação do ensino fundamental, onde ocorrem os maiores índices de violência escolar.

A escola como instituição, não pode ser uma multiplicadora de atos violentos, e nem deixar de agir, na forma da lei, para impedir que a violência estabeleça em sua área de atuação. E para que isso aconteça é preciso identificar quais os tipos de atos violentos que ocorrem no ambiente escolar. A Sociologia divide a violência em três categorias: - A violência autoinflingida que compreende atos suicidas ou autodestruitivo; - A segunda categoria é a violência interpessoal, subdividida, a título de estudo, em duas subcategorias, a familiar, que ocorre na

14 Reportagem publicada pelo G1 em 28/08/2018. Disponível em: <https://g1.globo.com/monitor-daviolencia/noticia/2018/08/28/brasil-registra-mais-de-26-mil-assassinatos-no-10-semestre-de2018.ghtml>. Acesso em: 23 jun. 2019. 
família, entre casais ou com qualquer membro do convívio, dentro do espaço que ele deveria ser protegido, e a comunitária, cujos autores e vítimas são conhecidos, mas não são da mesma família, e sim membros da comunidade; - A terceira categoria é a violência coletiva, que também se subdivide em violência política e violência econômica. Vale lembrar que a violência tem várias facetas e características. E que em busca de entendimento, pela trajetória conceitual deste fenômeno, encontramos diversos tipos de violências e cada conceito tem suas definições que se destacam em: - Violência moral que é toda ação que causa dano ou coloque em risco a autoestima, à identidade ou ao desenvolvimento da pessoa; ${ }^{15}$ - A violência institucional que ocorre no interior das instituições por meio de regras, normas de funcionamento, relações burocráticas e políticas, reproduzindo estruturas sociais injustas $;^{16}$ - A violência interpessoal ocorre quando a relação comunicacional dá-se com prepotência, intimidação, discriminação, raiva, vingança e inveja. Nesse tipo de violência, os conflitos, que fazem parte das relações sociais e humanas são transformados em intolerância e autoritarismo; ${ }^{17}$ - A violência contra o patrimônio é a praticada contra a parte física da escola. Estar contra a própria construção que se voltam os pré-adolescentes e os adolescentes, obrigados que sejam a passar mais que cinco a oito horas diárias; ${ }^{18}$ - A violência doméstica é a praticada por familiares ou pessoas ligadas diretamente ao adolescente ${ }^{19}$ - A violência simbólica é a que a escola exerce sobre o aluno, quando anula a sua capacidade de pensar, e o torna um ser somente capaz de reproduzir. Essa violência também pode ser contra 0 professor quando este é agredido em seu trabalho pela indiferença e desinteresse do aluno; ${ }^{20}$ - A violência física é brigar, bater, matar, suicidar, estuprar, matar, roubar, assaltar, tiroteio, espancar, pancadaria, sangramento, guerra, andar armado, e participar das atividades das gangues; ${ }^{21}$ - A violência física intrafamiliar ocorre

15 BRASIL, Conselho Federal de Psicologia. VI Seminário de Direitos Humanos "Nenhuma forma de violência vale a pena". Brasília DF, Junho de 2008. p. 13.

16 SOUZA, Edinilsa Ramos de. Curso: Impactos da Violência na Saúde. Rio de Janeiro: EAD/ENS, 2007. (Unidade I - Bases conceituais e históricas da violência e setor saúde).

17 SOUZA, 2007.

18 COLOMBIER, Claire; MANGEL, Gilbert; PERDRIAULT, Marguerite. A violência na escola. São Paulo, Ed. Summus, 1989.

19 COLOMBIER et al. 1989.

20 ABRAMOVAY, Miriam. Escola e violência, Miriam Abramovay et al.- Brasília: UNESCO, UCB, 2002. p. 335.

21 ABRAMOVAY, Miriam; et al. Gangues, galeras, chegados e rappers. RJ, Ed. Garamond, 1999. 
predominantemente na relação familiar e a maioria dos casos acontece dentro de casa e tem como principais agressores os próprios pais biológicos. ${ }^{22}$

Na bíblia há diversos relatos sobre a violência. Ela oferece informações históricas sobre os conflitos humanos. E por apresentar a visão de pelo menos quarenta autores, que viveram em tempos diferentes, e que escreveram seus livros, ao decorrer de um período aproximado de mil e seiscentos anos de história, podem nos oferecer diversos pontos de vista sobre o mesmo tema, enriquecendo-o com aspectos filosóficos e culturais.

Na história bíblica encontramos a violência como manifestação pecaminosa do ser humano. O capítulo seis de Gênesis afirma que naquele tempo havia gigantes na terra. Eles eram homens de renome, que provavelmente haviam ficado famosos pelo tamanho que tinham, pois com isso intimidavam os outros. A maldade multiplicou-se tremendamente na terra, e toda a imaginação do coração humano era continuamente má. ${ }^{23}$ A terra estava desprovida de valores morais e espirituais, tornando-se corrompida diante de Deus, e cheia de violência. ${ }^{24}$ Foi neste clima que um homem chamado Lameleque celebrou seus atos violentos como se fossem motivos para contar vantagem: "E disse Lameleque a suas mulheres: Ada e Zilá, ouvi a minha voz; vós mulheres de Lameleque, escutai o meu dito: porque eu matei um homem porque me feriu, e um menino, porque me machucou." 25 Vemos neste homem da história bíblica um caráter violento e cruel, ao demonstrar uma personalidade cheia de ira, implacável e fria.

A violência é um problema antigo, que afeta todas as sociedades, já existentes na história. Por isso não nos surpreende que ela seja levada para o ambiente escolar, uma vez que está presente nos relacionamentos, nas casas, nas ruas, na vida.

Na bíblia não só estão relatadas histórias de atos violentos, mas também as consequências destes atos. $O$ relato bíblico oferece um vasto documentário do fim daqueles que se deixaram levar pelo sentimento de vingança, ódio, inveja e violência.

\footnotetext{
22 SILVA, Maria Aparecida Alves da. A violência física intrafamiliar como método educativo punitivo-disciplinar e os saberes docentes. Goiânia, 2008.

Bíblia. AT. Antigo Testamento. Gênesis, cap. 6, ver. 5.

Bíblia. AT. Antigo Testamento. Gênesis, cap. 6, ver. 11.

25 Bíblia. AT. Antigo Testamento. Gênesis, cap. 4, ver. 23.
} 
A Igreja de Jesus Cristo pode e deve intervir neste relevante assunto, como coadjuvante no compromisso de resgatar o senso de família, revitalizando os laços de amizade entre pais e filhos, combatendo as diversas formas de violência, bem como a evasão escolar, e assim promover os estudantes e valorizar os professores e as professoras, dando uma contribuição substancial para a sociedade. E essa igreja, pode ser representada neste processo de cooperação entre instituições e agências, pelo trabalho da capelania, como uma ferramenta que visa identificar formas de mediação de conflitos, prevenção e intervenção a violência na escola.

\title{
2.2 A mídia e a violência
}

Desde o seu surgimento, a televisão vem influenciando gerações, através de seus conteúdos. Conforme Guareschi:

\begin{abstract}
Além de construir a realidade, associar uma dimensão de valor à notícia comunicada ela (TV) também monta a agenda de discussões, isto é, ela traz os assuntos sobre os quais as pessoas vão falar e refletir. Isso leva a conclusões muito sérias, pois nos damos conta de que a força da mídia não está apenas no que ela apresenta: está também, e muito, no que deixa de apresentar. ${ }^{26}$
\end{abstract}

Ao abordar a relação entre mídia, mais especificamente a televisão, e a educação, Fisher defende que a educação atua como um processo de formação de sujeitos da cultura, e que a televisão é um dos campos construtores da cultura contemporânea. Uma interação que a autora denomina como "dispositivo pedagógico da mídia”. ${ }^{27}$ Entendendo assim, a televisão, apresenta-se não apenas como recurso didático para a prática educativa, mas também como espaço eivado de elementos culturais, presentes, ainda, em muitos outros espaços sociais. Para a autora, portanto, a mídia televisiva é um meio que interage ativamente na constituição do social, da política e da cultura.

[...] queremos tratar da TV como criação, como produção cultural que nos oferece uma série de possibilidades de expressão audiovisual, de comunicação de sentimentos, ideias, indagações, informações; ao mesmo tempo, desejamos fazer desse estudo da TV uma forma de pensar os problemas, as possibilidades e os impasses da educação na contemporaneidade - fortemente marcada por alguns sintomas culturais, relacionados às mudanças tecnológicas nas diferentes práticas de

${ }^{26}$ GUARESCHI, Pedrinho. Sociologia Crítica - alternativas de mudança. EDIPUCRS, 1999. p. $138,139$.

27 FISCHER, Rosa Maria Bueno. Televisão \& Educação: fruir e pensar a TV. Belo Horizonte: Autêntica Editora, 2001. p. 7. 
comunicação e de informação de nosso tempo, e modos de aprender e de ensinar, certamente alterados justamente pela existência desse e de outros meios de comunicação e informação". ${ }^{28}$

A televisão interage de forma tão intensa no cotidiano, que sua capacidade de difundir conteúdos torna-se um parâmetro do que é público, conforme aquilo que ela registra e apresenta. Nesta dimensão, Fisher chama atenção para o desafio que o campo da comunicação televisiva representa para a educação, afirmando que em muitos casos, a televisão chega a substituir a escola como meio de informação e formação e, até mesmo, como referência de comportamento dos indivíduos.

A TV - poderíamos dizer - opera como uma espécie de processador
daquilo que ocorre no tecido social, de tal forma que "tudo" deve passar por
ela, "tudo" deve ser narrado, mostrado, significado por ela. Não há dúvidas,
por exemplo, de que a TV seria um lugar privilegiado de aprendizagens
diversas; aprendemos com ela desde formas de olhar e tratar nosso próprio
corpo até modos de estabelecer e de compreender diferenças de gênero
(isto é, de como "são" ou "devem ser" homens e mulheres), diferenças
políticas, econômicas, étnicas, sociais, geracionais. As profundas alteraçôes
naquilo que hoje compreendemos como "público" ou "privado" igualmente
têm um tipo de visibilidade especial no espaço da televisão, e da mídia de
um modo geral.

A TV instiga desejos, aproxima culturas, dita regras de conduta. Tudo isso tendo os recursos do som e da imagem como atrativos. A TV atua na área dos valores, ajudando a construir imagens e conceitos. Seu surgimento alterou valores e impôs costumes, formando, mesmo dentro dos desníveis socioeconômicos, uma população totalmente envolvida por suas informações. Por isso dá-se a necessidade de educar para a mídia. Conhecer um pouco da história deste veículo de massa que rapidamente conquistou as famílias brasileiras faz-se necessário para iniciar o entendimento sobre a influência da televisão na indústria cultural brasileira e no comportamento social, que é indiscutível.

É percebido que o tema violência escolar é pouco discutido dentro de um macro contexto educacional. E quando este tema é debatido em encontros e congressos são poucos divulgados, motivo pela qual não tem um alcance amplo e uma frente macro que esteja focada em colocar em ação as medidas já existentes de prevenção e repressão a violência na escola. Possibilitando que os oportunistas, maus profissionais de diversas áreas, usem a escola como uma cobaia para seus experimentos. Experimentos estes, que não agregam melhorias e mudanças no

28 FISCHER, 2001, p. 17.

29 FISCHER, 2001, p. 16. 
processo de transformação do quadro de violência nas escolas do nosso país. E geralmente chagam ao conhecimento da sociedade, quando por algum motivo viram escândalos ou tragédias, que mais servem como matérias de reportagem para serem vendidas pela mídia, principalmente a televisiva.

Em busca de uma melhor compreensão das causa deste fenômeno que cresce em nossa sociedade nos nossos dias precisaremos estudar a relação mídia e educação.

Ao abordar a relação entre mídia, mais especificamente a televisão, e a educação, podemos perceber que a televisão é um dos meios que tem maior amplitude para manobrar ou não as massas e influenciar no processo de construção ou destruição da cultura contemporânea, em todas as áreas da sociedade brasileira.

Segundo Fischer, a educação atua como um processo de formação de sujeitos da cultura, e a televisão é um dos campos construtores da cultura contemporânea. Uma interação que a autora denomina como "dispositivo pedagógico da mídia”. ${ }^{30}$ Entendendo assim, a televisão, apresenta-se não apenas como recurso didático para a prática educativa, mas também como espaço cheio de elementos culturais, presentes, ainda, em muitos outros espaços sociais. Para a autora, portanto, a mídia televisiva é um meio que interage ativamente na constituição do social, da política e da cultura.

\subsection{A problemática da violência nas escolas municipais em Taubaté-SP}

A cidade de Taubaté está localizada no Vale do Paraíba, Estado de São Paulo. O Vale é uma região muito procurada por desenvolver atividades econômicas importantes para o crescimento do país, através das indústrias de grande porte, centros tecnológicos e institutos de pesquisas que estrategicamente estão instalados entre duas metrópoles, São Paulo e Rio de Janeiro. Esta região possui ainda um número considerável de universidades, e a construção civil permanece gerando empregos para muitas pessoas. A região é cortada por grandes rodovias, bem localizada, no eixo Rio-São Paulo, e cidades turísticas de litoral, como Ubatuba, e serrana como Campos do Jordão, que ficam próximas da cidade de Taubaté. Em contrapartida, as cidades do Vale do Paraíba tem chamado a atenção pelos

30 FISCHER, 2001, p. 7. 
elevados índices de criminalidade. A região atualmente é líder no que se refere à criminalidade no interior do Estado de São Paulo, ultrapassando áreas mais populosas, como Campinas e Ribeirão Preto. Taubaté ganhou destaque como a cidade mais violenta do Vale do Paraíba no ano de 2012, sendo que o número de homicídios foi o que mais chamou a atenção. Em consulta ao site da Secretaria de Segurança Pública do Governo do Estado de São Paulo e ao Fórum Criminal de Taubaté, verificou-se que no primeiro semestre do ano de 2012, foram registrados 34 casos de homicídio doloso, 2.112 de furtos, 621 de roubos, e 842 de furtos e roubos de veículos. E, ano após ano, a criminalidade aumentou. Principalmente o crime contra a vida, o homicídio.

A violência, de acordo com o Dicionário contemporâneo da Língua Portuguesa, é a ação de constranger física ou moralmente uma pessoa para submetê-la aos desejos de outra. É ainda: forçar, obrigar, constranger, violar, torcer o sentido de, fazer alguma coisa ou consenti-la contra vontade. ${ }^{31}$

A questão da violência e suas consequências tem sido uma das principais preocupações no Brasil. O continuo incremento da violência, configura-se como um aspecto representativo e problemático da atual organização de nossa vida social, adquirindo formas específicas de manifestações nas diversas esferas da vida cotidiana. $^{32}$

A violência escolar tem como cerne as complexidades das causas com ênfase no contexto familiar, socioeconômico, cultural e escolar. É necessário apurar olhares para amenizar e combater o aumento de qualquer tipo de violência na escola, e este não pode ser atribuído tão somente a um fator determinante ou a vulnerabilidade. E para isso é necessário identificar e compreender quais tipos de violência têm enfrentado a escola, e como essa violência afeta os alunos e professores em sala de aula? Se a formação acadêmica tem contribuído positivamente para que os professores compreendam e lidem com o fenômeno da violência escolar?

A data de 7 de abril, é o dia nacional de combate ao bullying e à violência nas escolas. Foi instituída em 2016, por meio da Lei no 13.277. A escolha da data

31 AULETE, Caldas. Dicionário contemporâneo da Língua Portuguesa. 3 ed. Rio de Janeiro: Delta, 1980. v. 5. E pode ser acessado em: <http://www.aulete.com.br/>.

32 WAISELFISZ, Julio Jacobo. Mapa da violência: Crianças e adolescentes do Brasil. Rio de Janeira: Flacso, 2012. p. 7. 
está relacionada à tragédia que ocorreu em 2011, quando um jovem de 24 anos invadiu a Escola Municipal Tasso de Oliveira, no bairro de Realengo, no Rio de Janeiro, e matou 11 crianças. ${ }^{33}$

Assistimos inúmeras vezes, as notícias de tragédias veiculadas pela mídia escrita e televisionada. E todas as vezes que a sociedade tem acesso a essas informações, espanta-se e indaga com a mesma pergunta: o que está acontecendo com nossos jovens?

"Dupla ataca escola em Suzano, mata 8 pessoas e se suicida. Entre as
vítimas, estão alunos do ensino médio e funcionários, além do tio de um dos
assassinos. Onze ficaram feridos. Os assassinos eram ex-alunos do
colégio." "Um estudante de 17 anos foi preso suspeito de esfaquear um
professor nesta quinta-feira, 13 , na escola municipal Doutor Benedito Maia,
localizada no conjunto Abelardo Conduru, bairro do Coqueiro, em
Ananindeua, no estado do Pará. O ataque ocorreu dentro da sala de aula,
informou a polícia".

Especialistas em educação fizeram um alerta sobre os diversos tipos de violência em sala de aula, que envolvem agressão contra professores e professoras, preconceito contra alunos e alunas, cobrança excessiva por alto desempenho escolar e ausência de diálogo entre escola e comunidade. $O$ assunto foi discutido em audiência pública da Comissão de Educação da Câmara no dia 23/11/2017. E nesta ocasião foram apresentados os dados da pesquisa Prova Brasil que entrevistou diretores, alunos e professores do $5^{\circ}$ e $9^{\circ}$ anos do ensino fundamental em 2015. E nestes dados aparece o percentual de $57,5 \%$ das escolas públicas brasileiras, ao menos dois professores relataram ter sofrido algum tipo de violência, na maioria, agressão verbal. "Chama muita atenção que esse percentual em 2013 era de 52\%", observou Caio Callegari, representante do movimento Todos pela Educação. Segundo ele, em um estudo realizado pela instituição em 2016, com 1500 jovens de 15 a 19 anos, a segurança no ambiente escolar foi apontada como o maior atrativo da escola, atrás da acessibilidade e da infraestrutura, sobretudo pelos alunos do Centro-oeste, Sul e Nordeste. O mesmo estudo mostrou que a falta de segurança preocupa a maioria dos estudantes no Sul, Sudeste e Norte. Uma parte

33 Reportagem publicada no Site do Ministério da educação em 6/01/2010. E pode ser acessado em: $<$ http://portal.mec.gov.br/component/>.

34 Reportagem publicada pelo G1 Mogi das Cruzes/SP em 13/03/2019. Disponível em: <https://g1.globo.com/sp/mogi-das-cruzes-suzano/noticia/2019/03/13/tiros-deixam-feridos-emescola-de-suzano.ghtml>. Acesso em: 14 jun. 2019.

35 Reportagem publicada no Site conexão política em 14/06/2019. Disponível em: <https://conexaopolitica.com.br/Ultimas/aluno-esfaqueia-professor-em-sala-de-aula-no-para/>. Acesso em: 14 jun. 2019. 
do quebra-cabeça é a falta de integração entre as famílias e a comunidade com a escola. Têm de trazê-las para o debate, porque (a violência) é um problema que existe fora da escola. Não dá para fazer um trabalho em que a escola olhe só para o próprio umbigo. Callegari citou uma política pública bem-sucedida de integração da comunidade com a escola aplicada em Taboão da Serra (SP). Ao levar os professores para a casa dos estudantes, para que eles conversassem com as famílias, e ao trazer as famílias para dentro da escola, para participar efetivamente das decisões escolares, o resultado foi à resolução de muitos conflitos domésticos e também de conflitos dentro da escola". ${ }^{36}$

A Declaração Universal dos Direitos Humanos, pedra fundamental de nossa moderna convivência civilizada, estabelece, no seu art. $3^{\circ}$, que "todo indivíduo tem direito à vida, à liberdade e à segurança pessoal" e adiciona, no art. $5^{\circ}$ : "ninguém será submetido à tortura nem a penas ou tratamentos cruéis, desumanos ou degradantes". Mais recente, a Declaração Universal dos Direitos da Criança estabelece, no seu Princípio VI - Direito ao amor e à compreensão por parte dos pais e da sociedade, que "a criança necessita de amor e compreensão, para o desenvolvimento pleno e harmonioso de sua personalidade".

A Constituição Federal estipula, no seu art. 227: "É dever da família, da sociedade e do Estado assegurar à criança, ao adolescente e ao jovem, com absoluta prioridade, o direito à vida, à saúde, à alimentação, à educação, ao lazer, à profissionalização, à cultura, à dignidade, ao respeito, à liberdade e à convivência familiar e comunitária, além de colocá-los a salvo de toda forma de negligência, discriminação, exploração, violência, crueldade e opressão". ${ }^{37}$

Nosso Estatuto da Criança e do Adolescente, promulgado em 1990, considerado por muitos como um dos mais avançados do mundo, também contempla, no seu art. $4^{\circ}$ : "É dever da família, da comunidade, da sociedade em geral e do poder público assegurar, com absoluta prioridade, a efetivação dos direitos referentes à vida, à saúde, à alimentação, à educação, ao esporte, ao lazer,

\footnotetext{
36 Portal da Câmara dos Deputados. Disponível em: <https: //www2.camara.leg.br/camaranoticias /noticias/educao-e-cultura/549652-especialistas-alertam-para-aumento-da-violencia-nas-escolaspublicas.html>. Acesso em: 15 jun. 2019.

37 BRASIL. Constituição Federal, 1988.
} 
à profissionalização, à cultura, à dignidade, ao respeito, à liberdade e à convivência familiar e comunitária". 38

Em se tratando de combate a violência, pode-se perceber que no Brasil, existem normas previstas em legislação própria, voltadas para a proteção da infância e a juventude. Porém as políticas públicas voltadas para o combate à violência, não tem impedido 0 avanço da mesma no ambiente escolar, principalmente a que se processa na relação de convivência entre alunos, e entre alunos e professores. Mas os problemas não começam na escola. Percebe-se que eles desaguam nela, pois tem origens que extrapolam as fronteiras e limites da escola.

Ao mencionar a violência escolar, é possível perceber que este ambiente reflete a manifestação dos impasses e preocupações oriundos das áreas política, emocional, social, econômica, entre outras, "onde as subjetivações das condições vividas nesse tempo acontecem de forma intensa e com toda radicalidade". ${ }^{39}$

A violência sofrida por professores e alunos no ambiente escolar, gerada por diversos fatores, é um tema atual e muito presente na sociedade brasileira. Ainda, é considerada como fator que interfere na prática pedagógica do professor em diferentes níveis de ensino. ${ }^{40}$

Mas quais são as causas que mais interferem e prejudicam o processo de ensino- aprendizagem? O que impede a escola de reagir e mudar este quadro de aumento da violência? As escolas têm profissionais capacitados para lidar com esta problemática?

A violência exerce sobre a escola os seus efeitos, e é de suma importância conhecer e estudar três tipos mais amplos de violência: violência contra a escola, violência da escola e violência na escola. ${ }^{41}$

- Violência contra a escola: a depredação do patrimônio escolar e os baixos salários de docentes estariam relacionados a este tipo de violência.

BRASIL. Estatuto da Criança e do Adolescente, 1990.

39 JUSTO, J. S. Indisciplina/disciplina: ética, moral e ação do professor. 3 Ed. Atual. ortog. Porto Alegre: Mediação, 2010. p. 27.

40 PARRAT-DAYAN, S. Como enfrentar a indisciplina na escola. Tradução de Silva Beatriz Adoue e Augusto Juncal. São Paulo: contexto, 2008. p. 143.

41 Os três tipos de violência na escola: Disponível em: <https://site.cfp.org.br/os-tres-tipos-deviolencia-na-escola/>. Acesso em: 17 nov. 2018. 
- Violência da escola: a organização da escola, como mantenedora da exclusão racial, social, econômica, de gênero, agravado pelo silêncio dos educadores diante de tais preconceitos faz parte deste tipo de violência.

- Violência na escola: está ligada diretamente aos conflitos gerados nos relacionamentos interpessoais.

A conjunção da violência estrutural e violência social resultam na violência interpessoal. $^{42}$

As relações interpessoais intrafamiliar e extrafamiliar não estão dissociadas, uma vez que elas têm um peso significativo no processo de vulnerabilidade das crianças e dos adolescentes. Na medida em que os recursos materiais e subjetivos (afetivos) faltam no interior das famílias, não há como contrapor as ameaças externas, muitas vezes levando a criança e adolescente ao abandono do lar, ficando à mercê da exploração sexual, traficantes de drogas, e de se envolver com outros delitos (roubos, furtos, latrocínio, homicídios, etc.). Neste contexto estão sendo consideradas não somente a dinâmica e composição familiar, mas elementos externos ligados diretamente a ela, tais como o desemprego, o desenraizamento em busca de oportunidade de sobrevivência e o aumento da situação de pobreza, provocando a exclusão social, material e simbólica (ausência de poder e representatividade).

Tal situação poderá desencadear outras formas de violência intrafamiliar: física, psicológica, sexual, fatal negligência e abandono, transformando as relações em espaços disciplinadores dos filhos, ao invés de ser o espaço de proteção inerente ao ambiente familiar. Inseridas em ambientes com tantas restrições materiais e afetivas, e abundantes em violências, poucas alternativas restam às crianças e adolescentes. ${ }^{43}$

42 LIBÓRIO, Renata Maria Coimbra. "Exploração sexual comercial infanto-juvenil: categorias explicativas e políticas de enfrentamento." In: LIBÓRIO, Renata Maria Coimbra; SOUSA, Sônia M. Gomes (org.). Exploração sexual de crianças e adolescentes no Brasil: reflexões teóricas, relatos de pesquisa e intervenções psicossociais. São Paulo: Casa do Psicólogo; Goiânia: Universidade Católica de Goiás, 2004. p.19-50.

43 MORESCHI, Marcia Teresinha. Violência contra Crianças e Adolescentes: Análise de Cenários e Propostas de Políticas Públicas. Disponível em: <https://www.mdh.gov.br /violncia-contracriancas-e-adolescentes-analise-de-cenarios-e-propostas-de-politicas-publicas $>$. Acesso em: 28 jun. 2019. 



\section{A PARCERIA DAS IGREJAS COM ESCOLA, E A APLICABILIDADE DAS MEDIDAS PROTETIVAS PREVISTAS NO ESTATUTO DA CRIANÇA E DO ADOLECENTE NO SISTEMA FAMÍLIAR}

\subsection{A história da capelania e da capelania escolar}

Entende-se por "capelania escolar" ou "capelania educacional", o ramo da capelania voltada para a ação pastoral dentro das escolas ou instituições de ensino (creches, educação infantil, ensino fundamental, ensino médio, cursinhos, EJA e universidades). E tem como objetivo principal proclamar o Evangelho de Jesus Cristo voluntariamente, como uma forma de promover socorro social, emocional e espiritual as pessoas enlutadas, enfermas, aprisionadas e desorientadas.

Existe uma história, conhecida como a lenda de São Martinho, que relata que num rigoroso inverno europeu no ano de $338 \mathrm{DC}$, um jovem soldado repartiu a sua capella (capa ou manto) com um pobre homem que dormia na rua, agonizando de frio. Ele repartiu sua capa com o objetivo de atender a necessidade do outro. A partir daí surgiria o nome capelão, ou seja, alguém que atende, ou supre às necessidades humanas, sejam elas espirituais, pessoais ou sociais.

A tarefa da capelania também inclui a divulgação de importantes informações e orientações das diversas áreas que possibilitam uma melhor convivência no ambiente escolar e familiar, de forma que o esforço missionário urbano contribua com o crescimento, desenvolvimento e empoderamento da pessoa neste ambiente, possibilitando com estas experiências em campo, que sejam agregados importantes valores para serem disseminados pelos próprios alunos da escola.

A capelania escolar é um serviço de apoio e assistência espiritual, comprometida com a formação integral do ser humano no resgate dos valores construtivos. É uma área vasta e com muito potencial de abrangência, contudo a literatura escrita a respeito é bastante escassa. As bibliografias encontradas acabam focando em duas áreas mais exploradas, como a capelania militar e a capelania hospitalar. Apesar da existência de instituições de ensino centenárias que desde sua fundação têm utilizado essa ferramenta. Podemos definir capelania como: "Um 
serviço de apoio e assistência espiritual comprometida com a visão da integralidade do ser humano (corpo, emoções, intelecto, espírito)". ${ }^{44}$ Sua função é a de orientar e encorajar nos momentos de crise, reavivando a fé e a esperança de quem necessite, fazendo-se presente nos momentos de crises da vida, compartilhadas no aconselhamento pastoral, nas visitas aos hospitais, consolando e trazendo alento nos velórios. A capelania escolar possui um público-alvo variado, que parte dos alunos e seus familiares ou responsáveis diretos até os colaboradores do corpo docente e administrativo; enfim, todos os que se envolvem ou são envolvidos no processo educativo, e que estejam passando por conflitos na esfera pessoal e familiar. $^{45}$

A capelania escolar evidenciou-se em muitas das escolas confessionais evangélicas no Brasil. Essas escolas foram organizadas no século XIX, sendo que muitas delas tinham a finalidade principal de evangelizar, para isso eram necessárias à alfabetização e a educação do povo. Entre os batistas, presbiterianos e metodistas, surgiram os grandes colégios, fundados por missionários norteamericanos que vieram para o Brasil. Paralelamente ao trabalho educativo, os pastores realizavam o aconselhamento pastoral e a evangelização, ensaiando os primeiros modelos de capelania escolar. ${ }^{46} \mathrm{O}$ termo capelania tem sua origem militar na França. Nos campos de batalha, em tempos de guerra, montava-se uma tenda especial, onde era mantido um sacerdote para ofícios religiosos e aconselhamento. A tenda era chamada de "capela". O costume foi se perpetuando mesmo em tempos de paz e, com o tempo, o sacerdote que cuidava dela passou a ser chamado de "capelão". O serviço estendeu-se também a outras instituições como: hospitais, cemitérios e prisões, chegando ao contesto escolar. ${ }^{47}$ Mas apesar de muitas escolas de origem protestante ainda permanecerem firmes no cenário educacional brasileiro e a cada dia surgirem mais escolas evangélicas novas, o oferecimento de serviços de capelania parece encolher ou ser menos presente a cada década. Não obstante, aumenta a sua necessidade e crescem os desafios que as escolas enfrentam, aos quais a capelania poderia ajudar em muito como suporte ou em sua solução. Ao mesmo tempo, reconhecemos que os fatores intimidadores e limitadores para uma

\footnotetext{
44 VIEIRA, Walmir. Capelania Escolar, 2011. p. 13.

45 VIEIRA, 2011, p. 19-20.

46 FERREIRA, Damy. Capelania Escolar Evangélica, 2008. p. 30.

47 FERREIRA, 2008, p. 27.
} 
ação pastoral mais efetiva também têm crescido. Mas se a capelania escolar for considerada unicamente como um ministério de evangelização, deveria assumir um status de caráter emergencial em todas as escolas do nosso país. No entanto ela é recomendada por sua pluralidade ministerial, isenta de proselitismo.

Um dos pontos positivos da escola é que possui espaço físico que possibilita a realização de eventos que acolham contingentes numerosos para fins de eventos evangelísticos, celebrações, cerimônias, palestras, cultos, entre outras atividades que corroboram com a transmissão de conhecimento. Estes eventos agregam valores e melhoram a convivência por meio de relacionamento entre classes de diferentes idades, credos e raça, demonstrando que é possível estabelecer uma cultura de paz com as nossas crianças, nossos jovens e adolescentes. Naturalmente os e as jovens possui uma maior clareza da vida em sociedade, que as crianças, mas também tem maiores preocupações relacionadas com o futuro profissional. A maioria dos jovens e adolescentes, mora com seus pais, e estão em plena crise de identidade. Crise de identidade esta, que tem relação direta com a complexidade que é o ser humano e suas diversas identidades (Genética, ontológica, sexual, psicológica, relacional e social), sendo que elas estão interligadas e em constante mudança e evolução. "A falta de integração de todas as partes desse eu (masculino /feminino, bom/mau, superego admirado/ superego desprezado) consequentemente cria um falso eu". ${ }^{48}$ Assim muitos sofrem de isolamento, solidão e ausência de sentimento de pertencimento, portanto uma das funções da capelania escolar é apresentar-se como inclusiva, com o fim de agregar grupos que proporcione aos estudantes, uma convivência harmoniosa, pacífica e espiritual, que os encorajam a prosseguirem com seus estudos até que alcancem seus objetivos. Estas conquistas pessoais no ambiente de convivência escolar servem como estímulo positivo para convivência com o mundo, e os estimulam a irem mais alto, e sempre mais alto. Muitos, após obtiverem sucesso por meio dessas experiências, provavelmente se tornarão agentes promissores de transformação no ambiente onde forem inseridos, e procurarão reproduzir, na vida de outras pessoas, aquilo que lhes gerou esperança.

48 VERDE, J. B.; GRAZIOTTIN, A. Transexualismo: o enigma da identidade. São Paulo, 1997. p. 20. 
A capelania escolar cristã apresenta uma alternativa prática e funcional, para promover uma transformação no cenário de violência escolar, por meio do ensino bíblico, dentro do contexto e realidade das escolas no Brasil. Realidade esta que ocorre principalmente no ensino público, onde há uma maior inserção na educação básica $^{49}$, que engloba a educação infantil (de 0 a 6 anos), o ensino fundamental (de 7 a 14 anos), e o ensino médio (de 15 a 17 anos), das crianças, jovens e adolescentes de famílias de classes sociais mais baixas. "Mas diante desta afirmação será necessário responder a algumas perguntas básicas: por que o ensino da Bíblia funciona como uma forma de combate à violência? Como ensinar a Bíblia sem confundir a escola com uma igreja? É possível usar a Bíblia no ensino religioso sem desrespeitar as diferenças? Até que ponto o capelão pode ser direto e objetivo sobre os valores bíblicos dentro do ambiente escolar?". ${ }^{50}$ Essas questões são de extrema importância, mas formam uma complexa equação a ser resolvida, e é neste ponto que entra a figura do capelão escolar, para encontrar respostas equilibradas e claras, que possibilite a compreensão e aplicação dos ensinamentos bíblicos no contexto escolar. As respostas a essas perguntas estão mais relacionadas à preparação do capelão, que envolve treinamento e atualização constante para atuar na área de ensino religioso. Onde lhe serão exigidos grande responsabilidade e ética, para transmitir conhecimento sem utilizar da linguagem excessivamente formal dos seminários e das academias educacionais quando 0 público for o corpo de alunos da escola. A escola não é a igreja. E é por isso que na escola pública a abordagem usada na igreja mais repele que atrai as pessoas.

Ao ensinar, o capelão deve ser prático, com habilidade para contextualizar a lição à realidade dos alunos. Vale lembrar que no ambiente escolar desfilam diversas linhas religiosas, confissões e filosofias, que precisam ser todas respeitadas. Isso não significa concordar, é preciso fazê-lo com ética, amor e respeito. ${ }^{51}$

Um dos grandes desafios do capelão no ambiente escolar é gerar um ambiente de relacionamento, que possibilite desfazer os mitos, estabelecidos por anos, nas mentes das pessoas de forma destorcida. Por exemplo: Deus e papai

\footnotetext{
49 Lei de Diretrizes e Bases da Educação (LDB - 9.394/96)

50 FERREIRA, Sergio Rodrigues. Violência escolar: a bíblia e as alternativas de enfrentamento desse mal. São Paulo, 2014. p. 6.

51 FERREIRA, 2014, p. 15.
} 
Noel serem os mesmos; a bíblia é um livro desatualizado e com linguagem arcaica; a bíblia é só para os cristãos. Muitas vezes o próprio capelão precisa desmistificar conteúdos, conceitos, princípios e valores, que são mal compreendidos e ensinados de forma equivocada pela sociedade para os seus filhos que compõe as comunidades escolares. Por isso é preciso ter uma visão aberta, uma linguagem simples e contextualizada, para entender as diversas atividades curriculares, a fim de intervir com sabedoria quando elas vierem contrapor os valores, e princípios fundamentas da vida em comunidade. O capelão-professor jamais poderá esquecer que o conteúdo que ele ensina, é por força da lei, facultativo. Assim, os alunos não ter obrigatoriedade de frequentar as aulas de ensino religioso e nem os projetos que envolvem atividades de cunho religioso. Diante deste pressuposto, o capelão deverá conquistar os alunos com criatividade, e métodos não convencionais de ensino para atingir o seu objetivo. Tratar de temas do cotidiano dos alunos, estimulando a interatividade, fazendo com que a participação de todos e todas enriqueça o conteúdo da sua aula, dando voz e oportunidade de exposição de pensamentos e novas ideias sobre os temas em questão. Por isso, o capelão escolar busca entender o outro em suas necessidades diversas, com uma palavra amiga e com amor prático, aprendido no livro de Deus, e a partir deste referencial da verdade e da justiça, não se coloca diante da comunidade escolar como dogmático e nem juiz. Busca conhecer a pessoa de seus alunos, sem perder a esperança, para viver os valores eternos no ambiente escolar.

\subsection{A estrutura relacional e comportamental das pessoas crianças e adolescentes na Escola Docelina}

A escola não é a única responsável pelas tarefas expostas. Nóvoa se refere às "evoluções desejáveis para pensar e agir no campo educativo", trazendo como sugestões "a escola centrada na aprendizagem" e como um "espaço público de educação com um novo contrato educativo". ${ }^{52}$ Esse espaço público sugerido por Nóvoa, pode ser entendido com a frase "À escola o que é da escola; à sociedade o que é da sociedade". Essa sugestão está intimamente ligada à ideia de escola centrada na aprendizagem por essa só ter "sentido se a sociedade se

52 NÓVOA, A. Modelos de análise em educação comparada: o campo e a carta. In: SOUZA, D. B.; MARTINEZ, S. A. (Orgs.). Educação comparada: rodas de além-mar. São Paulo: Xamã, 2009. p. 83-84. 
responsabilizar, progressivamente, por um conjunto de missões que, até agora, têm sido assumidas pela escola". ${ }^{53}$

É nesse contexto que surge uma das maiores vulnerabilidades na estrutura relacional e comportamental na Escola Docelina. Pois as famílias têm transferido a responsabilidade de educar para a escola, e este fato tem sobrecarregado a escola, com responsabilidades que não são diretamente suas. E tendo em vista que o ambiente escolar não é o ambiente adequado para que sejam tratados os inúmeros problemas de ordem familiar, que envolvem os agentes que compõem as famílias dos alunos, a escola se tornou um ambiente de muitos embates.

Para Canário (2005) a escola tornou-se um ambiente de muitos embates. Perdeu aquela dupla ligação a qual apresentava até na metade do século $X X$ : coerência interna (baseada no entendimento entre a sua clientela e as sugestões da escola) e coerência externa (a sociedade depositava nela grandes expectativas). Para o sociólogo português, os jovens enfrentam grandes dificuldades, como a falta de emprego num mundo violento, oscilante e competitivo. Acredita que a incerteza "é o mais difícil de todos os estados psicológicos". ${ }^{54}$ Diante disso, a escola tem se tornado um espaço de proliferação de violência. São várias causas que justificam e explicam os indisciplinados, os acontecimentos agressivos e conflitos na formação escolar. O conflito é uma conjuntura de enfrentamento de dois ou mais atores, entre os quais existe a rivalidade aguçada por alguma desigualdade de preferências. Esses conflitos podem se tornar agressivos quando falham os recursos conciliadores que consentiriam um enfrentamento tranquilo, pacífico. O conflito escolar atribui diversos modelos, como a desordem, a violência entre pares, e as provocações professor e aluno, etc. Todas essas causas são colocadas como "falta de disciplina", em que geralmente os alunos são penalizados com suspensões, de acordo com cada regimento interno (direitos e deveres dos alunos) da escola.

Educar é ensinar a construir uma fraternidade universal e cósmica através de ensinos relevantes para toda a sociedade e para todos os seres humanos. ${ }^{55}$

\footnotetext{
3 NÓVOA, 2009, p. 89.

54 CANÁRIO, Rui. O que é escola? Um "olhar" sociológico. Portugal, Porto Editora, 2005. p. 81.

55 ESCLARÍN, Antônio Pérez. Educar para humanizar. São Paulo: Paulinas, 2006. p. 15.
} 
Ensinar é educar com convicção de que seus ensinamentos podem mudar a realidade de seus aprendizes e que eles poderão tornar-se sujeitos de suas próprias vidas, adquirindo autonomia. ${ }^{56}$

O Estatuto da Criança e do Adolescente (ECA), de 1990, é um importante marco regulatório da infância e da adolescência no Brasil. E nele está estabelecida a idade, de cada fase deste processo de transformação crescente e amadurecimento progressivo, nas vidas das pessoas crianças e adolescentes. O Estatuto da Criança e do Adolescente (ECA) define que as crianças são as pessoas com a idade entre 0 a 12 anos incompletos, e os adolescentes são as pessoas, com idades entre 12 e 18 anos completos, e ainda, que eles são sujeitos de direitos e pessoas em desenvolvimento.

O Estatuto da Criança e do Adolescente (ECA) é considerado um marco inovador, pois estabelece um parâmetro que os distinguem dos adultos e possibilita a criação uma rede de proteção por meio de lei, quando estabelece atribuição identitária de sujeitos de direitos para as crianças e os adolescentes, e as enquadram como pessoas em condições especiais de desenvolvimento. $O$ fato de que ainda estão em desenvolvimento e que não são adultas, ainda leva a condição de que elas ainda não teriam ainda condições emocionais, cognitivas e sociais, de defenderem o seus próprios direitos.

Para entendermos melhor a condição das crianças e dos adolescentes, podemos analisar a teoria de Vygotsky, que define que o desenvolvimento humano é histórico, e aborda aspectos do indivíduo enquanto espécie e sua relação sociocultural.

Podem-se distinguir, dentro de um processo geral de desenvolvimento, duas linhas qualitativamente diferentes de desenvolvimento, diferindo quanto à sua origem: de um lado, os processos elementares, que são de origem biológica, de outro, as unções psicológicas superiores, de origem sociocultural. A história do comportamento da criança nasce do entrelaçamento dessas duas linhas. A história do desenvolvimento das funções psicológicas superiores seria impossível sem um estudo de sua pré-história, de suas raízes biológicas, e de seu arranjo orgânico. As raízes do desenvolvimento de duas formas fundamentais, culturais, de comportamento, surgem durante a infância: o uso de instrumentos e a fala humana. ${ }^{57}$

56 FREIRE, Paulo. Pedagogia do oprimido. 7 ed. Rio de Janeiro: Paz e Terra, 1979. p. 76.

57 VYGOTSKY, L. S. A formação social da mente. São Paulo: Martins Fontes, 2007. p. 42. 
A pessoa criança e adolescente vivem diversas experiências transformadoras de suas histórias pessoais e familiares. Sendo assim, podemos nos pautar de que elas são sujeitos ativos, sociais e históricos, capazes de constituir os seus próprios contextos e transformar os contextos de suas famílias e instituições a qual transitam em sua trajetória de vida.

O sujeito de Vygotsky é compreendido como uma unidade múltipla, que não se totaliza, posto que, está em constante transformação de si mesmo e do seu contexto, e que se realiza "na relação eu-outro, sendo constituído e constituinte do processo sócio-histórico". 58

\title{
3.3 O Professor e o Capelão, e a comunicação relacional
}

É inegável que o professor é a autoridade em sala de aula, dirige a atividade pedagógica e é um profissional da educação. Entretanto, as modificações de conhecimento e de evolução curricular estão modificando a passos enormes. É importante ressaltar que o aluno mudou, a sociedade e a escola mudaram. Antigamente, esperava-se que o aluno se adaptasse ao professor. Hoje, é o professor quem deve adaptar-se ao tipo de aluno com quem convive. ${ }^{59}$

\begin{abstract}
A sociologia da educação deve, é claro, dar conta da relação entre o fato de pertencer a uma classe e o fracasso escolar. Mas também deve dar conta do fato de que essa relação não é mecânica. A explicação do fracasso escolar em termos de distância cultural entre o aluno e a escola deve, em primeiro lugar, ser construída no nível mais concreto: por um lado, o da distância entre a cultura que uma criança particular deve à sua família e, por outro, o currículo real e as normas de excelência com as quais é confrontada cotidianamente em uma sala de aula particular. ${ }^{60}$
\end{abstract}

O exemplo e o relacionamento estável dos pais influenciam bastante os filhos. Um casamento feliz fará mais para preparar os jovens para a vida, que regras e vigilância. Uma demonstração consistente de virtudes cristãs, como amor, paciência, compreensão, encorajamento e confiança, dará a base que o adolescente necessita em tempos de tensão e mudanças.

58 MOLON, Susana Inês. Subjetividade e constituição do sujeito em Vygotsky. Petrópolis, RJ: Vozes, 2003. p.116.

59 NÓVOA, 2009, p. 89.

60 PERRENOUD, Philippe. A ambiguidade dos saberes e da relação com o saber na profissão de professor. In: Ensinar: agir na urgência, decidir na incerteza, do mesmo autor. Porto Alegre: Artmed Ed., 2001. p. 131. 
A comunicação relacional é uma das ferramentas adotada pelo capelão escolar, em busca de mediar conflitos, prevenir e intervir nos processos que geram violência, com o intuito de estabelecer a paz e motivar os indivíduos envolvidos a agirem de forma que possam desenvolver uma empatia uns pelos outros, o estabelecimento de um ambiente harmonioso.

$\mathrm{Na}$ dimensão sacerdotal a capelania escolar procura zelar pela vida comunitária e individual das pessoas, cuidando da espiritualidade, da qualidade de vida e, desta forma, trabalhando por uma ética comunitária. Cardoso elucida que estes elementos expressam-se de diversas maneiras: nas celebrações litúrgicas; no consolo e solidariedade aos que sofrem; no aconselhamento pastoral; no estímulo e na preservação do diálogo juntamente com os espaços democráticos; no incentivo a alteridade e a inclusão. ${ }^{61}$

Conceituamos comunicação relacional como um método de comunicação integral que busca capacitar pessoas para transmitir e/ ou decodificar ideias, sentimentos e comportamentos com vistas ao bom entendimento das pessoas e à melhoria da convivência particular e coletiva. Sendo assim a sua instrumentabilidade, se sintetiza em capacitar pessoas de modo pleno para os relacionamentos, tanto pessoais e familiares quanto profissionais e sociais. Tais proposituras partem de premissa consagrada pela sociologia, antropologia, psicologia, entre outras áreas da ciência, que o homem é um ser social, isto é, somos em nossa essência seres relacionais, que em todas as esferas de nossa vida temos a necessidade de formar e desenvolver vínculos, tendo como canal a comunicação. ${ }^{62}$

Quando falamos de comunicação relacional, nos referimos aos seus elementos constitutivos. $\mathrm{E}$ isto significa tratar das três áreas desta comunicação: a afetiva, a comportamental e a do temperamento.

A comunicação afetiva é uma ferramenta de criação de vínculos afetivos em nossos relacionamentos. É o modo pela qual transmitimos e recebemos amor.

61 CARDOSO, Luis de Souza. Apontamentos sobre pastoral e capelania em escolas metodistas. Revista de Educação do COGEIME, n. 21, p. 113-123, 2002. p. 114.

62 CARNEIRO, Alex Ribeiro. Comunicação relacional: um instrumento de gestão pessoal e estratégia corporativa. São Paulo, Ed. Teneo Publishing House, 2018. 
O capelão escolar busca desenvolver os aspectos ligados à linguagem afetiva que os estudantes, professores e colaboradores da escola possuem, procurando entender como estas pessoas comunicam afeição, para através de sua intervenção fortalecer a autoestima deste público alvo e assim gerar empatia. Podendo assim criar maior harmonia nos relacionamentos no ambiente escolar $\mathrm{e}$ fora dele.

O propósito da capelania neste aspecto da comunicação relacional é aperfeiçoar os relacionamentos e potencializá-los para construção de vínculos que edifiquem e que permitam o crescimento de todos os envolvidos. Nesta linha, são significativas as palavras de Paulo de Tarso:

Não saia da vossa boca nenhuma palavra torpe, mas só a que for boa para promover a edificação, para que dê graça aos que a ouvem. [...] Toda a amargura, e ira, e cólera, e gritaria, e blasfêmias, e toda malícia seja tirada de entre vós. Antes, sede uns para com os outros benignos, misericordiosos, perdoando-vos uns aos outros, como também Deus vos perdoou em Cristo. ${ }^{63}$

Partindo da premissa que a pessoa humana é um ser social, o capelão escolar acredita que o crescimento das pessoas em um relacionamento saudável é capaz de refletir em outras pessoas e outros relacionamentos.

O ser humano é relacional, tem a necessidade de vínculos pessoais, e precisa comunicar-se afetivamente, porque tem necessidades e expectativas que precisam ser atendidas pelos seus vínculos relacionais.

Estudos da Universidade de Yale-EUA, revelou que: 'os solitários apresentam uma probabilidade duas vezes maior de morrer. [...], estar rodeado por pessoas com as quais podemos contar exerce uma grande influência em nossa capacidade de resistir à tempestade e de nos recuperarmos. ${ }^{64}$

A comunicação relacional é primordial, pois é fator determinante para formação e desenvolvimento dos relacionamentos.

Os frutos de uma comunicação relacional afetiva, eficiente e eficaz, dão origem a uma serena comunicação relacional comportamental. E os agentes envolvidos neste processo, independente do seu tipo de temperamento, herança genética, tende a se melhor compreendido, e a compreender os outros. Fato este que potencializa este instrumento de graça, gerando empatia e consequentemente

63 Bíblia Sagrada. Novo Testamento. Efésios, cap. 4, ver. 29-32.

64 GOTTIMAN, John M. Relacionamentos. Rio de Janeiro: Ed. Objetiva, 2003. p. 71. 
um ambiente harmonioso. Estudo sobre inteligência emocional explica este processo da seguinte forma:

O primeiro tipo de compreensão é fruto da mente emocional, o outro, da mente racional. $\mathrm{Na}$ verdade, temos duas mentes a que raciocina e a que sente (...), quanto mais intenso o sentimento, mais dominante é a mente emocional. ${ }^{65}$

O fato é que o capelão escolar como mediador de conflitos, lida muitas vezes com pessoas reagindo de certo modo irracional, no ambiente escolar. As reações, movidas por sentimentos e emoções, aparecem primeiro. E é por isso que o capelão deve associar a linguagem afetiva com a comportamental, para analisar a origem de um determinado comportamento. Devendo partir do pressuposto que os sentimentos se expressam por nosso comportamento.

A comunicação relacional comportamental envolve a reação, a expressão, as mensagens que surgem com os gestos, o tom de voz das pessoas. Estas atitudes e reação traduzem sentimento ou pensamento de seus autores. E é por meio destes sinais que o capelão pode captar o verdadeiro sentido do que se quer informar. ${ }^{66}$

65 GOLEMAN, Daniel. Inteligência Emocional. Rio de Janeiro: Ed. Objetiva, 1997, p. 23.

${ }^{66}$ CARNEIRO, 2018, p. 61, 64. 



\section{ENTRANDO EM AÇÃO: POSSIBILIDADES E PROJETOS}

\subsection{Apresentando as possibilidades}

A Constituição Federal de 1988, no Artigo 210, $\S 1^{\circ}$, determina que o ensino religioso, de matrícula facultativa, constituirá disciplina dos horários normais das escolas públicas do ensino fundamental. $O$ interessante é que a mesma, não proíbe o ensino religioso nos outros níveis de escolaridade, como o ensino médio e superior.

Pela facultabilidade, o Ensino Religioso mostra-se como uma disciplina autônoma, diversa de história, sociologia, filosofia, ciência da religião, com isso, conclui-se que ela é uma matéria confessional, ou seja, é apoiada na fé e não uma matéria científica.

O Estado é laico, ou seja, é neutro sob a forma da lei. O Artigo 19, inciso I, CF - VEDADO: I - "Estabelecer cultos religiosos ou igrejas, SUBVENCIONÁ-LOS, embaraçar-Ihes o funcionamento ou manter com eles ou seus representantes relações de dependência ou aliança, RESSALVADA, na forma da lei, $A$ COLABORAÇÃO DE INTERESSE PÚBLICO". Os exemplos de colaboração de interesse público que estão na forma da lei no Preâmbulo: - "Nós, representantes do povo brasileiro, [...] promulgamos, SOB A PROTECÃO DE DEUS, a seguinte Constituição da República Federativa do Brasil"; - No Artigo 5º inciso VII, CF: "É assegurada, nos termos da lei, a prestação de assistência religiosa nas entidades civis e militares de internação coletiva" (Capelania na CF); - Vedado imposto sobre templo de qualquer culto religioso - artigo 150, inciso VI, "b", CF; - Casamento religioso com efeito civil - artigo 226, § 2ํㅡ, CF; - Outros exemplos: SAÚDE EDUCAÇÃO (artigo 213, I e II, CF).

No âmbito do Estado de São Paulo existe a Lei n. 10.783/2001 e o Decreto no 46.802/2002 no Artigo 4ㄴ, está estabelecido que, fica a Secretaria da Educação autorizada a expedir as orientações necessárias para o processo de atribuição de aulas de Ensino Religioso para os professores pertencentes ao quadro do magistério da Secretaria da Educação. E em seu parágrafo único estabelece que as exigências relativas à habilitação do professor para ministrar as aulas devem estar em 
conformidade com a Deliberação № 16/2001, do Conselho Estadual de Educação, órgão normativo do sistema de ensino.

Há ainda a Deliberação no 16/2001 - CEE, que estabelece no Art. 8o, que as escolas estaduais disponibilizarão, ainda, às instituições religiosas das mais diversas orientações, horário para oferta de ensino confessional, de caráter facultativo para os alunos. Conforme os seguintes parágrafos: $-\S 1^{\circ}-$ As atividades a serem desenvolvidas ficarão a cargo de representantes das diferentes instituições, na forma de trabalho voluntário; - $\S 2^{0}$ - Autorização para o uso de espaço do prédio escolar para o ensino religioso de natureza confessional será feita sob a responsabilidade da escola, a partir de programação elaborada pela instituição interessada e aprovada pelo Conselho da Escola; e $§ 3$ - A matrícula facultativa dos alunos em turmas de ensino religioso confessional somente será realizada mediante conhecimento dos pais sobre a natureza do conteúdo e autorização expressa dos mesmos.

Mesmo com amparo em lei, o capelão precisa evitar em suas ministrações no ambiente escolar de fazer proselitismo.

O proselitismo é a manobra, a tática para conquistar fiéis, com propaganda religiosa à custa de condenações das outras religiões e de artimanhas para atrair adeptos. O proselitismo consiste em rebaixar, ridicularizar, combater as outras religiões, colocando-se numa situação de superioridade e vantagem.

Segundo o Dicionário Online de português, proselitismo é o "esforço contínuo para converter alguém, fazendo com que essa pessoa pertença a determinada religião, seita, doutrina; catequese: proselitismo religioso" ${ }^{67}$

\subsection{O Projeto Brincando com Graça}

O Projeto Brincando com Graça (BG) é um projeto oferecido pelo ministério de missões da Igreja Batista da Graça, localizada à Avenida Francisco Alves Monteiro, 1107, Parque Senhor do Bonfim, Taubaté-SP, CNPJ 14049575000103, sem fins lucrativos, e é exercido em escolas públicas e outras instituições de ensino, com o objetivo de ensinar princípios, valores e virtudes e, ainda, abordar temas

67 Dicionário Online de português. Significado de proselitismo. Disponível em: <https://www.dicio.com.br//>. Acesso em: 15 nov. 2019. 
cotidianos da vida dos alunos e das alunas, com o fim de proporcionar melhorias pessoais e interpessoais, no âmbito escolar.

O Brincando com Graça (BG) é um projeto social de Recreação Infantil. E tem como um dos objetivos realizar brincadeiras que ministrem nas crianças princípios morais e sociais, que as façam trabalhar em equipe e se importar com o próximo em um processo de inclusão social. O projeto em questão é realizado por voluntários todos os sábados em um período das 9 hs às 11 hs.

O projeto Brincando com Graça (BG) já acontece há cinco anos e meio, na quadra coberta da Escola Municipal de Educação Infantil e Ensino Fundamental (EMIEF) Professora Docelina Silva de Campos Coelho no bairro Santa Tereza em Taubaté-SP, sendo aprovado pela Secretaria de Educação da cidade.

O Estatuto da Criança e do Adolescente (ECA) - Lei Federal n 8069/1990, proibi o trabalho para menores de quatorze anos de idade, salvo na condição de aprendiz, e aponta o direito à liberdade, incluindo o brincar, a prática de esportes e a diversão, conforme o artigo 16, inciso IV: "Art.16 - O direito à liberdade compreende os seguintes aspectos: (...), IV. brincar, praticar esportes e divertir-se".

É na educação infantil onde a escola dá maior liberdade para que o capelão utilize de sua criatividade, iniciativa e inovação, para que a brincadeira assuma sua forma específica, e seja um instrumento para elevar a autoestima das crianças, auxiliando-as a superar progressivamente suas aquisições de forma criativa, transformando os conhecimentos que já possuíam em conceitos gerais com os quais brincam.

A brincadeira é uma linguagem infantil que mantém um vínculo essencial
com aquilo que é o 'não brincar'. Se a brincadeira é uma ação que ocorre no
plano da imaginação, isto implica que aquele que brinca tenha o domínio da
linguagem simbólica. Isto quer dizer que é preciso haver consciência da
diferença existente entre brincadeira e a realidade imediata que lhe
forneceu conteúdo para realizar-se. Nesse sentido, para brincar é preciso
apropriar-se de elementos da realidade imediata de tal forma a atribuir-lhes
novos significados. Essa peculiaridade da brincadeira ocorre por meio da
articulação e a imitação da realidade. Toda brincadeira é uma imitação
transformada, no plano das emoções e das ideias, de uma realidade
anteriormente vivenciada. (...) A brincadeira favorece a autoestima das
crianças, auxiliando-as a superar progressivamente suas aquisições de
forma criativa. Brincar contribui, assim, para a interiorização de
determinados modelos de adulto, no âmbito de grupos sociais diversos. 
Essas significações atribuídas ao brincar transformam-no em um espaço singular de constituição infantil”. 68

O discurso se faz mais forte e presente na Educação Infantil. Porém, no Ensino Fundamental, ele desaparece se nos pautarmos apenas pelas Diretrizes Curriculares Nacionais, onde no documento redigido para a Educação Infantil, a questão da ludicidade encontra-se no artigo $3^{\circ}$, inciso I, alínea c e diz o seguinte:

"Art. $3^{\circ}$ - São as seguintes as Diretrizes Curriculares Nacionais, para a Educação Infantil: 1-As propostas pedagógicas das instituições de Educação Infantil devem respeitar os seguintes fundamentos norteadores: (...), c) os princípios estéticos da sensibilidade, da criatividade, da ludicidade e de manifestações artísticas e culturais".

Já no documento redigido para o Ensino Fundamental, a questão da ludicidade, desaparece, assim como mostra o art. $3^{\circ}$, inciso I, alínea c:

"Art. $3^{\circ}$ - São as seguintes as Diretrizes Curriculares Nacionais para o Ensino Fundamental: 1-As escolas deverão estabelecer como norteadores de suas ações pedagógicas: (...), c) os princípios estéticos da sensibilidade, da criatividade e da diversidade de manifestações artísticas e culturais".

Porém, ainda que exista todo esse amparo legal, não está garantido na prática, o direito de brincar. E assim, entre o discurso e a realidade, o tempo e o espaço do brincar, vão sendo reduzidos, sendo este, visto até mesmo como atividade oposta ao trabalho.

\begin{abstract}
"É importante demarcar que o eixo principal em torno do qual o brincar deve ser incorporado em nossas práticas é o seu significado como experiência de cultura. Isso exige que a garantia de tempos e espaços para que as próprias crianças e os adolescentes criem e desenvolvam suas brincadeiras, não apenas em locais e horários destinados pela escola a essas atividades (como os pátios e parques para recreação), mas também nos espaços das salas de aula, por meio da invenção de diferentes formas de brincar com os conhecimentos". 69
\end{abstract}

Um dos principais objetivos do Brincando com Graça (BG) é tornar o ambiente escolar propício ao aprendizado, favorecendo relacionamentos saudáveis e a evolução dos alunos e das alunas, em um espaço onde eles e elas possam externar bons princípios, valores e virtudes, tornando a prática do brincar em uma

68 Referencial Curricular Nacional para a Educação Infantil, 2002, p. 27.

69 BORBA, Ângela M. O brincar como um modo de ser e estar no mundo. In: BRASI, MEC/SEB Ensino fundamental de nove anos: orientações para a inclusão da criança de seis anos de idade/ organização Jeanete Beauchamp, Sandra Denise Rangel, Aricélia Ribeiro do Nascimento Brasília: Ministério da Educação, Secretaria de Educação Básica, 2006. p. 44. 
experiência cultural. E sendo assim, o brincar ganha uma dimensão de ato coletivo na escola e fora dela.

Como objetivos secundários, visamos alcançar as famílias dos alunos e das alunas, buscando uma evolução integral, impactando toda a sociedade e o sistema educacional.

O Brincando com Graça (BG) propõe efetivar a educação, em um ambiente propício a essa tarefa e, ainda, atender a faixa etária que tem a educação como definidor do seu progresso como indivíduo e cidadão.

Educar, segundo educadores, não é apenas a atividade de transmitir conteúdos e aferir notas, mas sim um processo contínuo, amplo e que abrange integralmente o ser e tudo ao se redor ${ }^{70}$, ou, ainda, a educação tem a finalidade de ensinar o indivíduo a conhecer, viver, conviver, fazer e a ser. ${ }^{71}$

Educar é ensinar a construir uma fraternidade universal e cósmica através de ensinos relevantes para toda a sociedade e para todos os seres humanos. ${ }^{72} \mathrm{E}$ ensinar é educar com convicção de que seus ensinamentos podem mudar a realidade de seus aprendizes e que eles poderão tornar-se sujeitos de suas próprias vidas, adquirindo autonomia. ${ }^{73}$

A educação ensina, mas não é qualquer ensino. A educação de verdade não ensina apenas a decorar, antes, ensina a construir, a desconstruir, a remontar, a elaborar, a criar, a ser pleno, a ser livre, a lutar. E com essa definição e relevância de educação, que o Brincando com Graça (BG), objetiva auxiliar a direção, professores e todos que almejam melhorar a vida de seus aprendizes, realizando a tarefa de educar efetivamente, por meio de princípios, valores e virtudes relevantes para o ser, e também, para toda a sociedade.

Os beneficiários diretos deste projeto são gerados nos alunos da educação Infantil e do ensino fundamental, e são direcionados aos professores e

70 MOLOCHENCO, Madalena de Oliveira. Curso vida nova de teologia básica: educação cristã. São Paulo: Vida Nova, 2007. p.16.

71 BARCO, Luiz. Educar para a cidadania: "desafio para a religião". In: OLIVEIRA, Pedro A. Ribeiro, MORI, Geraldo de (org.). Religião e educação para a cidadania. São Paulo: Paulinas; Belo Horizonte: Soter, 2011.

72 ESCLARín, Antônio Pérez. Educar para humanizar. São Paulo: Paulinas, 2006. p. 15.

73 FREIRE, Paulo. Pedagogia do oprimido. 7 ed. Rio de Janeiro: Paz e Terra, 1979. p. 76. 
colaboradores da escola. E os beneficiários indiretos são colhidos pelos familiares dos beneficiários diretos, sistema educacional e a sociedade como um todo.

\subsection{O Projeto CAPAZ}

O CAPAZ é um projeto elaborado pela Associação Alfa e ômega e a Mocidade para Cristo da Baixada Santista (MPC-BXS), com embasamento legal amparado no Art. 210, § 1ํㅡㄹ da Constituição Federal; Art. 33, da Lei № 9.394 (Lei Nacional de Diretrizes e Base da Educação); Lei Estadual ㄲo 10.783/2001; Decreto Estadual no 46.802/2002 e Art. 8o da Deliberação no 16/200, do Conselho Estadual de Educação de São Paulo. O projeto tem como objetivo ensinar princípios, valores e virtudes fundamentados na Bíblia, buscando a melhoria nos aspectos pessoais e interpessoais, em relação a todos os envolvidos em uma unidade escolar. E tem como desafio transmitir e explicar essas verdades universais (princípios), ensinar sobre esses conceitos interpretativos (valores) e mostrar a melhor fonte que impulsiona as melhores condutas (virtudes), pautados na Palavra de Deus.

A Associação Alfa e ômega e a Mocidade para Cristo da Baixada Santista (MPC-BXS) elaborou um caderno de lições composto de 34 (trinta e quatro) lições que são colocadas em prática semanalmente, em um período de 09 (nove) meses. Com a finalidade de fornecer conteúdo para aplicação das atividades de assistência educacional, programa semanal e contínuo, que além de conceituar amplamente o indivíduo como um ser integral, cada ensino transmitido tem uma aplicabilidade específica à família, visando ã preservação do vínculo familiar. Esse enfoque é pautado no art.4 ${ }^{\circ}$ do Estatuto da Criança e do Adolescente (ECA), reconhecendo a importância da família na formação integral do ser humano. O intuito é facilitar a efetivação dos direitos inerentes à convivência familiar, permeando-a com princípios, valores e virtudes.

As ministrações das lições seguem a ordem metodológica indicada para e elaborada do programa. Cada lição dura de 10 a 15 minutos é aplicada no intervalo das aulas correntes. Sempre iniciando com uma dinâmica (quebra-gelo) concernente com o tema proposto naquela semana. Visa motivar a interação entre os participantes voluntários (alunos, se possível professores). O conteúdo com base 
bíblica é ensinado sempre buscando interagir com os alunos, e se for autorizado encerra-se com oração.

Pensar a infância, a adolescência e a educação no momento atual requer um grande esforço e uma profunda reflexão por parte da escola e da sociedade, que estão alarmadas com ocorrência do aumento de atos de suicídios, automutilação, depressão, e outros tipos de patologias e degradação do ser humano. Assistimos atônitos, veicular na mídia que os nossos jovens estão sem esperança, como nos reporta a seguinte reportagem escrita em 05 de setembro de 2018 pela Redação do Quiririm News, com a seguinte informação:

Taubaté registra mais de cem tentativas de suicídio em menos de um ano. Um estudo feito pela Vigilância Epidemiológica de Taubaté fez um comparativo entre o ano de 2017 e o ano de 2018 até o mês de agosto que alerta para o aumento no número de casos de tentativa de suicídio na cidade. O resultado aponta 72 tentativas sendo 11 casos consumados em 2017 contra 123 tentativas sendo 9 casos consumados até o dia 15 de agosto deste ano. Os dados mostram um aumento de $70,6 \%$ no número de tentativas em 2018. Em relação ao levantamento deste ano, as faixas etárias predominantes apontam para jovens de 21 a 30 anos (36 casos) e 16 a 20 anos (31 casos) sendo o envenenamento o método mais procurado (97 casos). ${ }^{74}$

Infelizmente neste ano de 2019, o índice de tentativa e de suicídio em Taubaté-SP, segundo a pesquisa divulgada na campanha do setembro amarelo, deste ano corrente, registra um aumento considerável em relação ao ano de 2018.

A campanha setembro amarelo tem adolescentes, como foco em Taubaté. Os adolescentes de 11 a 20 anos são a prioridade da campanha Setembro Amarelo em Taubaté. A ação visa reforçar a necessidade do bem-estar e da saúde mental contra o suicídio neste público-alvo. De acordo com a Prefeitura Municipal, a decisão de priorizar os jovens foi escolhida após o estudo dos dados da Vigilância Epidemiológica do município. De janeiro a agosto deste ano foram registradas 277 tentativas de suicídio na cidade. Deste total de casos, 30,68\% são de pessoas entre 11 anos e 20 anos. Ainda de acordo com a administração municipal, foram realizados 1.200 atendimentos de crianças e adolescentes com até 18 anos no município. Os jovens apresentavam sofrimento psíquico intenso, transtornos mentais de maior complexidade decorrentes do uso de álcool e outras drogas. Para a edição de 2019 do Setembro Amarelo, a Secretaria de Saúde de Taubaté montou uma programação com a realização de um dia de atividades para os servidores que trabalham com saúde mental no dia 17 e com o II Fórum

74 Reportagem do Portal de Notícias Quiririm News. Disponível em: $<$ https://quiririmnews.com.br/taubate-registra-mais-de-cem-tentativas-de-suicidio-em-menos-deum-ano/>. Acesso em: 23 out. 2019. 
de Prevenção ao Suicídio, que acontece este ano nos dias 25 e 26 no auditório de psicologia da UNITAU (Universidade de Taubaté). ${ }^{75}$

O suicídio de dois alunos em um período de quarenta dias no colégio ENTEC em Taubaté faz parte desta estatística. E esta tragédia juntamente com os pedidos de socorro de diretoras de algumas escolas municipais, nos encorajou a elaborar uma proposta de Projeto de Lei Ordinária onde apresentamos o Serviço Voluntário de Capelania Escolar como um serviço de assistência religiosa de apoio espiritual, comprometida com o ser humano de forma integral, para atuar nas unidades de ensino da Rede Pública Municipal de Educação de Taubaté-SP. Nesta ocasião propomos ao Vereador Jessé Silva que protocolasse e fizesse a apresentação em audiência pública na Câmara Municipal de Taubaté. E ao mesmo tempo protocolamos na Escola Docelina e na Secretaria de Educação de Taubaté dois ofícios. Um da Faculdade EST, para obter autorização para desenvolver a pesquisa bibliográfica e documental na referida escola e o outro para obter autorização para desenvolver o Serviço Voluntário de Capelania Escolar por meio do Projeto CAPAZ nas escolas da rede municipal de Taubaté-SP. O Projeto de Lei Ordinária foi aprovado na Câmara Municipal de Taubaté e está seguindo os trâmites legais. Em resposta aos ofícios que protocolamos, obtivemos a autorização e entramos em ação, com equipes de capelães e auxiliares ensinando virtudes, princípios e valores bíblicos na Escola Docelina e em outras escolas da Rede Pública de Ensino Municipal de Taubaté.

Após o ensino e aplicação dessas virtudes, princípios e valores, é possível visualizar a mudança comportamental, principalmente, dos alunos, dos professores, da direção, dos funcionários e de todo o ambiente, pessoal e interpessoal, da unidade que os recebe. Diante desses ensinos contundentes, relevantes para toda a sociedade e úteis para o convívio entre pessoas, o processo de educação, como meio de evolução integral do ser, é feito de forma sistêmica, gradual e efetiva.

Além do ambiente escolar, esses ensinamentos buscam impactar e transformar a realidade da família brasileira atual, entidade descaracterizada e comumente taxada como falida em meio à sociedade, pois não exerce seu papel de

75 Reportagem publicada em 11/09/2019 pela Redação do Guia Taubaté. Disponível em: <https://guiataubate.com.br/noticias/2019/9/campanha-setembro-amarelo-tem-adolescentes-comofoco-em-taubate>. Acesso em: 23 out. 2019. 
mantenedora, fundamento essencial e responsável pelo crescimento integral de seus membros. ${ }^{76}$

76 FRANÇA, Rafael da Silva. Souza, Marcos Vinicius Batista. Eu Sou Capaz: Amar, Viver, Ensinar. Brasília, 2019. 



\section{CONCLUSÃO}

Após a análise dos documentos que possibilitou esta pesquisa, foi possível identificar alguns fatores que favorecem a violência nas escolas municipais em Taubaté-SP: o alto índice de criminalidade nos bairros periféricos da cidade, onde reside, uma quantidade expressiva de alunos, que frequentam à mesma. Foram apontados ainda, como fatores que desencadeia uma série de outros problemas, o tráfico de drogas que cercam as instituições, as famílias desestruturadas, onde algum membro da mesma se corrompeu, ou pelo vício, ou pelos crimes impostos pelo tráfico. Segregando as famílias, com ocorrências de pais presos ou assassinados. O crescimento do desemprego.

Acredita-se que o grande desafio de professores e professoras desta escola deva ser o de assumir uma postura para o enfrentamento do problema da violência. O primeiro passo parece que já foi dado, quando a direção traçou o perfil familiar de cada estudante envolvido em situações de violência. O segundo passo é refletirem sobre as práticas pedagógicas aplicadas pelos professores em sala de aula, pois a partir daí, poderão surgir explicações e soluções, para os problemas de indisciplina e violência que ocorrem no cotidiano escolar.

Percebe-se ao se aproximar da turma de estudantes do sétimo ano, turma que desenvolvemos o projeto CAPAZ, uma vez por semana, que em sua maioria deixaram de sonhar com um futuro melhor, pois sofrem com a falta de participação ativa de suas famílias em sua formação. E essa ausência deixa uma lacuna difícil de ser preenchida no que diz respeito ao interesse e preocupação com o rendimento escolar e com as atitudes dos filhos. Sem receberem exemplos positivos em casa e nem cobranças para que se desenvolvam. $O$ resultado é a total falta de amor pela escola e a total falta de perspectiva de um futuro melhor.

O desafio das Igrejas e da Escola, exposto neste projeto piloto que iniciamos no Docelina é ensinar valores, princípios e virtudes cristãs aos alunos e trazer aos cooperadores da escola um incentivo para fazer mais do que simplesmente mapear os problemas, já que atribuí-los a questões externas, como a desestrutura familiar, o tráfico e a pobreza do bairro, praticamente exime a escola de culpa. Embora a profissão de professor seja repleta de impasses, desvalorização e especificidades, 
faz-se necessária que esta prática profissional seja embasada também em aspectos afetivos para a construção de uma nova relação, principalmente em locais como a instituição escolar aqui estudada.

A Escola Docelina, teve os seus maiores embates, com a indisciplina e violência, registrados no ano de 2015. Naquele mesmo ano uma equipe de missionários da Igreja Batista da Graça propôs à direção da escola o Projeto Brincando com Graça, e iniciou o projeto focado em resgatar valores, princípios e estabelecer limites que consequentemente iria fortalecer os relacionamentos afetivos, mudando o comportamento dos estudantes no ambiente escolar. E foi exatamente surpreendente, na opinião da diretora. Pois foi observado por ela e as professores da Escola Docelina, que os estudantes mais indisciplinados de alguma forma, apresentaram uma mudança em seu comportamento na sala de aula, e no pátio da escola onde ocorriam brigas e conflitos violentos.

"Tudo muda quando você muda" é exatamente o lema do Projeto Capaz criado pela Mocidade para Cristo (MPC) da Baixada Santista. Projeto que o Ministério de Capelania e Discipulado da Igreja Batista da Graça, iniciou este ano no Docelina. Os dois projetos se completam, pois o Brincando com Graça (BG) utilizando-se do lúdico atraem o interesse e participação voluntária das crianças e 0 Capaz alcança os Jovens e os adolescentes com os diálogos no formato de roda de conversa, com dinâmicas pautadas nos ensinamentos das histórias bíblicas e acompanhamento em discipulado de emancipação onde ocorrem os compartilhamentos de vida na vida, e os aconselhamentos. As capelãs discipulam as meninas, e os capelãos os meninos. Prática que tem permitido uma maior exposição de relatos das dificuldades, tristezas e alegrias que os mesmos têm vivido no seu cotidiano, nos possibilitando como capelãos, interceder para proteger, direcionar e estabelecer limites a pessoa criança e adolescente.

A disponibilidade para o diálogo deve ser iniciada no espaço da sala da aula e estar refletida em todas as ações pedagógicas que envolvam os sujeitos da educação, como bem defende Freire:

Nas minhas relações com os outros, que não fizeram necessariamente as mesmas opções que fiz no nível da política, da ética, da estética, da pedagogia, nem posso partir de que devo "conquistá-los", não importa a que custo, nem tampouco temo que pretendam "conquistar-me". É no respeito às diferenças entre mim e eles ou elas, na coerência entre o que faço e o que digo; que me encontro com eles ou com elas. É na minha 
disponibilidade à realidade que construo a minha segurança, indispensável à própria disponibilidade. É impossível viver a disponibilidade à realidade sem segurança, mas é impossível também criar a segurança fora do risco da disponibilidade. ${ }^{77}$

A partir das análises do Projeto Pedagógico (PP), que é um projeto político, de gestão de longo prazo, que traz a compreensão pedagógica que orientará a ação educativa da escola e determina os rumos, a intenção e os processos que a escola utilizará para alcançar suas metas. Do Regimento Escolar (RE), que é a lei maior da escola e é também o código de ética da instituição. Do Calendário Escolar (CE), composto de um cronograma onde constam todas as atividades, até mesmo, as extraclasses que ocorreram em todo ano letivo, o Plano de Ação (PA), que indica os objetivos e metas a serem alcançados pela escola no ano letivo. E por fim o Diário de Classe (DC), o mecanismo de gestão e de escrituração escolar que segue e controla o desenvolvimento das ações dos professores e alista todos os alunos matriculados por série, ciclo ou etapa, turno e turma, armazena o rendimento escolar, frequência, conteúdos programáticos, dias letivos, feriados e carga horária. Todos, documentos oficiais de gestão escolar da Escola Municipal Ensino Infantil e Fundamental Profa. Docelina Silva de Campos Coelho, em Taubaté-SP, podemos concluir que a parceria entre o serviço voluntário de capelania escolar e as escolas municipais na cidade de Taubaté-SP, tem contribuído para o enfrentamento à violência escolar, e fortalecido a rede de proteção à infância e a juventude. Fato este que é possível identificar ao observamos que a intervenção e o cuidado integral proporcionado pelo serviço voluntário de capelania escolar, reduziram os fatores estressores internos e externos, gerados pelas frustrações, desamparo, desesperança, desespero, e a impulsividade, particularmente entre os jovens, ouve uma diminuição expressiva dos casos de vandalismo, agressões físicas e verbais, e evasão escolar. Outra observação a ser feita é que não houve registro de suicídio no Docelina, o que cresce de grande importância, as atividades realizadas pelos capelães junto à comunidade escolar, estabelecendo modelos sociais que promovam a valorização da vida, e da saúde física e mental.

Entre os inúmeros transtornos enfrentados no município de Taubaté-SP, dentro do cotidiano escolar há um índice expressivo de suicídios entre crianças e adolescentes. E estes índices tem alarmado nossa comunidade nos últimos anos.

77 FREIRE, Paulo. Pedagogia da autonomia. Saberes necessários à prática educativa. 27 ed. São Paulo: Paz e Terra, 2003. p. 135. 
Além disso, questões como o "bullying" e depressão tem afetado o desenvolvimento intelectual e social de inúmeros estudantes.

A Capelania Escolar possui um público-alvo variado, que parte dos alunos e seus familiares ou responsáveis diretos até os colaboradores do corpo docente e administrativo; enfim, todos os que se envolvem ou são envolvidos no processo educativo e que estejam passando por conflitos nas esferas pessoal e familiar.

É do conhecimento de todos que dentro do ambiente escolar está presente a cultura pluralista e a diversidade religiosa. Faz parte da Ética da Capelania em qualquer âmbito, o respeito e a tolerância à crença alheia. $\mathrm{A}$ atitude de humildade $\mathrm{e}$ a demonstração de amor ao próximo devem prevalecer, sempre. Afinal, ninguém é dono da verdade e cada um possui o direito à liberdade de religião, amparado pela Bíblia, por tratados internacionais, pela Constituição Federal e pela legislação específica. Deve-se destacar, portanto, que a Capelania Escolar não faz proselitismo. As ações visam apenas o bem estar espiritual e psicológico do indivíduo, trazendo assim melhora considerável em sua qualidade de vida.

Nas instituições que adotaram o Projeto de Capelania, notou-se uma melhora significativa no ânimo dos professores, coordenadores, alunos e seus pais. Esse ambiente favorável tem repercussão direta na melhora do aprendizado, no ambiente fraterno em classe e extraclasse. 


\section{REFERÊNCIAS}

ABRAMOVAY, M., \& RUA, M. G. Violências nas escolas: Versão resumida. Brasília: UNESCO, 2003.

AULETE, Caldas. Dicionário contemporâneo da Língua Portuguesa. 3 ed. Rio de Janeiro: Delta, 1980. v. 5. E pode ser acessado em: <http://www.aulete.com.br/>.

BARCO, Luiz. Educar para a cidadania: "desafio para a religião". In: OLIVEIRA, Pedro A. Ribeiro, MORI, Geraldo de (org.). Religião e educação para a cidadania. São Paulo: Paulinas; Belo Horizonte: Soter, 2011.

BARDIN L. Análise de conteúdo. Lisboa: Edições 70, 2009.

BARROSO, João. Integração e Competências para uma nova visão de gestão. In FIGUEIREDO, Hermes et al. Liderança e Educação: Formação de líderes na dinâmica do ensino superior/organização de Fábio Garcia dos Reis. São Paulo: editora de Cultura, 2012.

Bíblia. Sagrada. Antigo Testamento. Gênesis, cap. 6, ver. 5, 11.

Bíblia Sagrada. Antigo Testamento. Gênesis, cap. 4, ver. 23.

Bíblia Sagrada. Novo Testamento. Efésios, cap. 4, ver. 29-32.

BLIN, Jean F. Classes Difíceis - Ferramentas para Prevenir e Administrar os Problemas Escolares. Porto Alegre: ArtMed, 2005.

BORBA, Ângela M. O brincar como um modo de ser e estar no mundo. In: BRASIL, MEC/SEB Ensino fundamental de nove anos: orientações para a inclusão da criança de seis anos de idade/ organização Jeanete Beauchamp, Sandra Denise Rangel, Aricélia Ribeiro do Nascimento - Brasília: Ministério da Educação, Secretaria de Educação Básica, 2006.

BRASIL, Constituição, 1988. Brasília: Câmara dos Deputados, Edições Câmara, 2011. 103p. Serie texto básico, n. 61.

BRASIL. Estatuto da Criança e do Adolescente, 1990. Disponível em: <http://www.planalto.gov.br/ccivil/LEIS/L8069.htm>. Acesso em: 03 dez. 2016.

BRASIL, Conselho Federal de Psicologia. VI Seminário de Direitos Humanos "Nenhuma forma de violência vale a pena". Brasília DF, 2008.

BRUNO, Lúcia. Poder administrativo no capitalismo contemporâneo. In: OLIVEIRA, Dalila Andrade (Org.). Gestão Democrática da Educação. Petrópolis: Vozes, 1997.

CANÁRIO, Rui. O que é escola? Um "olhar" sociológico. Portugal, Porto Editora, 2005. 
CARDOSO, Luis de Souza. Apontamentos sobre pastoral e capelania em escolas metodistas. Revista de Educação do COGEIME, n. 21, 2002.

CARNEIRO, Alex Ribeiro. Comunicação relacional: um instrumento de gestão pessoal e estratégia corporativa. São Paulo: Ed. Teneo Publishing House, 2018.

CARVALHO, José Murilo de. Cidadania no Brasil: o longo caminho. 5 ed. Rio de Janeiro: Civilização Brasileira, 2004.

COLEMAN, Daniel; HUSÉN, Torsten. Tornar-se Adulto numa sociedade em Mutação. Porto: Edições Afrontamento, 1990.

COLOMBIER, Claire; MANGEL, Gilbert; PERDRIAULT, Marguerite. A violência na escola. São Paulo, Ed. Summus, 1989.

COSTA, Jorge Adelino. Imagens Organizacionais da Escola. Lisboa: Edições Asa, 1996.

Dicionário Online de português. Significado de proselitismo. Disponível em: <https://www.dicio.com.br//>. Acesso em: 15 nov. 2019.

ESCLARÍN, Antônio Pérez. Educar para humanizar. São Paulo, Ed. Paulinas, 2006.

FERNÁNDEZ, I. Prevenção da violência e solução de conflitos: o clima escolar como fator de qualidade. São Paulo, Ed. Madras, 2005.

FERNANDES, Francisco; LUFT, Celso Pedro; GUIMARÃES, F. Marques. Dicionário Brasileiro Globo. 46 ed, São Paulo, 1996.

FERREIRA, Sergio Rodrigues. Violência escolar: a bíblia e as alternativas de enfrentamento desse mal. São Paulo, 2014.

FISCHER, Rosa Maria Bueno. Televisão \& Educação: fruir e pensar a TV. Belo Horizonte: Autêntica Editora, 2001.

FRANÇA, Rafael da Silva. Souza, Marcos Vinicius Batista. Eu Sou Capaz: Amar, Viver, Ensinar. Brasília, 2019.

FREIRE, Paulo. Pedagogia do Oprimido. 17 Ed. São Paulo: SP: Editora Paz e Terra, 1987.

FREIRE, Paulo. Pedagogia da autonomia. Saberes necessários à prática educativa. 27 ed. São Paulo: Paz e Terra, 2003.

FREUD, Anna. Infância normal e patológica (determinantes do desenvolvimento). 4 Ed. Rio de Janeiro: Ed. Guanabara, 1987.

GARCIA, J. Indisciplina na escola: uma reflexão sobre a dimensão preventiva. Revista Paranaense de desenvolvimento, Curitiba, n. 95, jan./abr. 1999. 
GIL, A. C. Como elaborar projetos de pesquisa. São Paulo: Atlas, 2002.

GOLEMAN, Daniel. Inteligência Emocional. Rio de Janeiro. Ed. Objetiva, 1997.

GOTTIMAN, John M. Relacionamentos. Rio de Janeiro, Ed. Objetiva, 2003.

GUARESCHI, Pedrinho. Sociologia Crítica - alternativas de mudança. EDIPUCRS, 1999.

JUSTO, J. S. Indisciplina/disciplina: ética, moral e ação do professor. 3 Ed. Atual. Ortog. Porto Alegre: Mediação, 2010.

LA TAILLE. Y. A indisciplina e o sentimento de vergonha. In: AQUINO, J. G. (Org.). Indisciplina na escola: alternativas teóricas e práticas. 8 Ed. São Paulo: Summus, 1996.

Lei de Diretrizes e Bases da Educação (LDB - 9.394/96).

LIBÓRIO, Renata Maria Coimbra. "Exploração sexual comercial infanto-juvenil: categorias explicativas e políticas de enfrentamento". In: LIBÓRIO, Renata Maria Coimbra; SOUSA, Sônia M. Gomes (org.). Exploração sexual de crianças e adolescentes no Brasil: reflexões teóricas, relatos de pesquisa e intervenções psicossociais. São Paulo: Casa do Psicólogo; Goiânia: Universidade Católica de Goiás, 2004.

MARTINEZ, S. A. (Org.). Educação comparada: rodas de além-mar. São Paulo: Xamã, 2009.

MOLON, Susana Inês. Subjetividade e constituição do sujeito em Vygotsky. Petrópolis, RJ: Vozes, 2003.

MORESCHI, Marcia Teresinha. Violência contra Crianças e Adolescentes: Análise de Cenários e Propostas de Políticas Públicas. Disponível em: $<$ https://www.mdh.gov.br /violncia-contra-criancas-e-adolescentes-analise-decenarios-e-propostas-de-politicas-publicas>. Acesso em: 28 jun. 2019.

MOSCOVICl, Serge. Representações sociais: investigações em psicologia social. Petrópolis, RJ, Ed. Vozes, 2009.

NÓVOA, A. Evidentemente - Histórias da educação. Porto: Edições ASA, 2005.

NÓVOA, A. Modelos de análise em educação comparada: o campo e a carta. In: SOUZA, D. B.; MARTINEZ, S. A. (Orgs.). Educação comparada: rodas de alémmar. São Paulo: Xamã, 2009.

ODALIA, N. O que é violência? São Paulo: Brasiliense, 2004.

Os três tipos de violência na escola. Disponível em: <https://site.cfp.org.br/os-trestipos-de-violencia-na-escola/>. Acesso em: 17 nov. 2018. 
PARRAT-DAYAN, S. Como enfrentar a indisciplina na escola. Tradução de Silva Beatriz Adoue e Augusto Juncal. São Paulo: contexto, 2008.

PERRENOUD, Philippe. A ambiguidade dos saberes e da relação com o saber na profissão de professor. In: Ensinar: agir na urgência, decidir na incerteza, do mesmo autor. Porto Alegre: Artmed Ed, 2001.

Portal da Câmara dos Deputados. Disponível em:

<https://www2.camara.leg.br/camaranoticias /noticias/educao-e-cultura/549652especialistas-alertam-para-aumento-da-violencia-nas-escolas-publicas.html>. Acesso em: 15 jun. 2019.

Referencial Curricular Nacional para a Educação Infantil, 2002.

Reportagem publicada pelo G1 em 28/08/2018. Disponível em: <https://g1.globo.com/monitor-da-violencia/noticia/2018/08/28/brasil-registra-maisde-26-mil-assassinatos-no-1o-semestre-de-2018.ghtml>. Acesso em: 23 jun. 2019.

Reportagem publicada no Site conexão política. Disponível em: <https://conexao politica.com.br/ Ultimas/aluno-esfaqueia-professor-em-sala-de-aula-no-para/>. Acesso em: 14 jun. 2019.

Reportagem publicada pela Redação do Guia Taubaté. Disponível em: <https://guiataubate.com.br/ noticias/2019/9/campanha-setembro-amarelo-temadolescentes-como-foco-em-taubate>. Acesso em: 23 out. 2019.

Reportagem publicada no Portal de Notícias Quiririm News. Disponível em: $<$ https://quiririmnews. com.br/taubate-registra-mais-de-cem-tentativas-de-suicidioem-menos-de-um-ano/>. Acesso em: 23 out. 2019.

ROLIM, Marcos. Discursos Selecionados: Pronunciamento do Deputado Federal Marcos Rolim PT/RS. Grande Expediente da Sessão Plenária do dia 21 de janeiro de 2000. Disponível em: <http://www.rolim.com.br/discur10.htm>. Acesso em: 18 mar. 2019.

SARTI, Cynthia Andersen. O jovem na família: o outro necessário. São Paulo: Ed. Fundação Perseu Abramo, 2004.

SPOSITO, M. P. A instituição escolar e a violência. Cadernos de pesquisa, São Paulo, n. 104, 1998.

SILVA, A. B. B. Bullying: mentes perigosas na escola. Rio de Janeiro: Ed. Objetiva, 2010.

SILVA, Maria Aparecida Alves da. A violência física intrafamiliar como método educativo punitivo-disciplinar e os saberes docentes. Goiânia, 2008.

SOUZA, Edinilsa Ramos de. Curso: Impactos da Violência na Saúde. Rio de Janeiro: EAD/ ENS, 2007. 
WAISELFISZ, Julio Jacobo. Mapa da violência: Crianças e adolescentes do Brasil. Rio de Janeiro: Flacso, 2012.

VASCONCELLOS, C. dos S.(In) Disciplina: Construção da disciplina consciente e interativa em sala de aula e na escola. 17 Ed. São Paulo: Libertard, 2009.

VERDE, J. B. e GRAZIOTTIN, A. Transexualismo: o enigma da identidade. São Paulo, 1997.

VIEIRA, Walmir. Capelania Escolar, desafios e oportunidades. São Paulo: Rádio Trans Mundial, 2011.

VYGOTSKY, L. S. A formação social da mente. São Paulo: Martins Fontes, 2007.

ZALUAR, Alba. Integração Perversa: Pobreza e Tráfico de Drogas. Rio de Janeiro: FGV, 2004. 